\title{
Chronic Allograft Dysfunction: A Model Disorder of Innate Immunity
}

\author{
Walter Gottlieb Land
}

\begin{abstract}
The innate immune system is a highly sensitive organ of perception sensing any cell stress and tissue injury. Its major type of response to all potential inciting and dangerous challenges is inflammation and tissue repair and, if needed, induction of a supportive adaptive immune response, the aim always being to maintain homeostasis. However, although initially beneficial, innate immunity-mediated, protection-intended repair processes become pathogenic when they are exaggerated and uncontrolled, resulting in permanent fibrosis which replaces atrophic or dying tissue and may lead to organ dysfunction or even failure. In this sense, atherosclerosis and organ fibrosis reflect classical disorders caused by an overreacting innate immune system. Strikingly, these two pathologies dominate the development of chronic allograft dysfunction as the main clinical problem still left in transplantation medicine. Growing evidence suggests that acute and chronic allograft injuries, including alloimmune-,

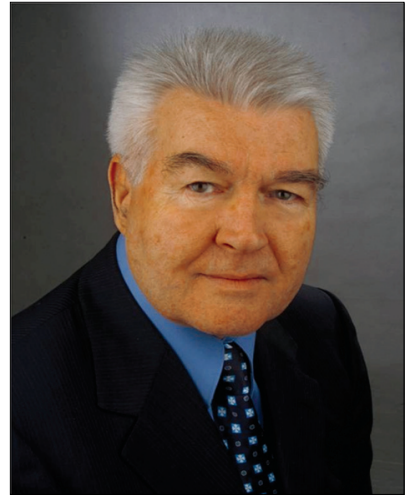

Prof. Walter Gottlieb Land isoimmune-, nonimmune-, and infection-mediated insults, not only lead to cell death-associated graft atrophy but also activate the innate immune system which, over time, leads to uncontrolled intragraft fibrogenesis, thereby compromising allograft function. Acute and chronic allograft injuries lead to induction of damage-associated molecular patterns (DAMPs) which, after recognition by pattern recognition receptors, activate cells of the innate immune system such as donor-derived intragraft fibroblasts and vascular cells as well as recipient-derived graft-invading macrophages and leukocytes. It is mainly the orchestrated action and function of these cells that slowly but steadily metamorphose the originally life-saving allograft into a poorly functioning organ of marginal viability. (Biomed J 2013;36:209-228)
\end{abstract}

\section{Key words: allograft injuries, atherogenesis, chronic allograft dysfunction, damage-associated molecular patterns, fibrogenesis, innate immunity}

\begin{abstract}
A decade ago, we proposed that chronic allograft rejection, also called as chronic allograft dysfunction (CAD), results from antigen-dependent and antigen-independent allograft injuries that elicit innate immune responses leading to fibrotic processes in the allograft as reflected by alloatherosclerosis and allofibrosis. ${ }^{[1,2]}$ In view of incredible progress in research on innate immunity, it is becoming apparent that our concept is largely true. Accordingly, in this article, recent evidence is collected in support of the notion that the etiopathogenesis of CAD - besides progressive loss of parenchymal cells - is dominated by
\end{abstract}

the processes of the donor's and recipient's innate immune system activated by various types of acute and chronic allograft injuries.

In the past, the innate immune system was primarily seen as a host defense system with its primary task to eliminate the invading pathogens. However, these views have changed. Today, the system is regarded as a highly sensitive organ of perception sensing any cell stress and tissue injury. The system's major type of response to all these different inciting and dangerous challenges is inflammation. ${ }^{[3]}$ The aim of the response

From the Molecular ImmunoRheumatology, INSERM UMR_S1109; Laboratory of Excellence (LabEx) Transplantex, Research Center for Immunology and Hematology, Faculty of Medicine, University of Strasbourg, 67085 Strasbourg Cedex, France

Received: Mar. 22, 2013; Accepted: Jun. 18, 2013

Correspondence to: Prof. Walter Gottlieb Land, German Academy of Transplantation Medicine, Germany. Koeglweg 32, 82024

Taufkirchen/Munich, Germany. Tel:49-1711463792; E-mail: wgland@gmail.com

DOI: $10.4103 / 2319-4170.117622$ 
is to provide any kind of protection including killing of invading pathogens, removing dead cells, repairing destroyed tissue, balancing metabolic or psychological irregularities, and finally, when foreign antigens are involved (such as microbial antigens, altered self-antigens, or alloantigens), inducing a supportive adaptive immune response. However, although initially beneficial, these innate immunity-mediated, protection-intended tissue repair processes become pathogenic when they are exaggerated and uncontrolled, resulting in deregulated cell differentiation and proliferation as well as substantial deposition of extracellular matrix (ECM) components in which severely damaged, atrophic, or dying tissue is replaced with permanent fibrotic tissue [Figure 1].

Thus, histology of chronically deteriorating allograft function, as for example observed in renal,,$^{[4]}$ heart, ${ }^{[5]}$ and lung transplantation, ${ }^{[6]}$ is dominated by a variety of fibrosing changes in the (micro) vasculature (alloatherosclerosis) and the interstitium (allofibrosis), often seen in the absence of acute inflammatory cellular infiltrates. Accordingly, CAD may be regarded as a model disorder of injury-induced, innate immunity-mediated atherosclerosis and organ fibrosis as a consequence of allograft injury-induced cell death and atrophy. The unique feature of this model is the fact that the innate immune system is activated by both immune and nonimmune allograft injuries.

In order to cover this topic, recent selected data from the exploding international literature are explored by high-

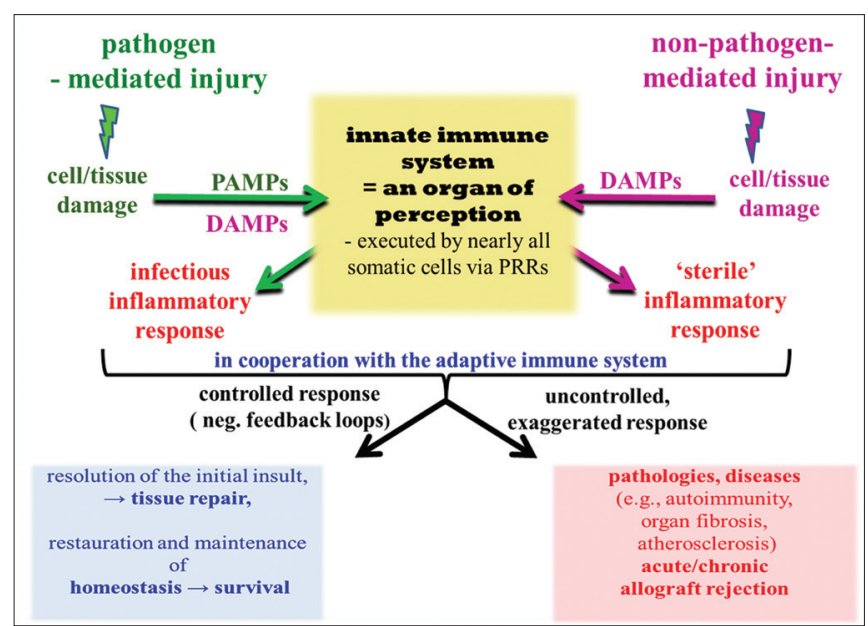

Figure 1: The innate immune system: A highly sensitive organ of perception sensing any cell stress and tissue injury. The highly conserved first-line defense system as represented by most somatic cells reacts to any tissue injury with an inflammatory response aiming to eliminate the inciting and dangerous challenges and to repair the destroyed tissue, thereby maintaining homeostasis. However, when uncontrolled and exaggerated, the system leads to diseases and pathologies including allograft acute and chronic allograft rejection. (DAMPs, damage-associated molecular patterns; PAMPs, pathogen-associated molecular patterns; PRRs, pattern recognition receptors) lighting innate immune mechanisms reported to be involved in injury-induced atherogenesis and fibrogenesis. Of note, because of space limitations, most references are review articles in which the original citations can be found.

\section{Injury-induced, innate immunity-mediated infectious and "sterile" inflammation}

Current notions in immunology hold that not only pathogen-mediated injury but also any tissue injury associated with cell damage activates the innate immune system that elicits an infectious or "sterile" inflammatory response. In fact, the phenomenon that "injury induces immunity" was discovered by our group two decades ago ${ }^{[7-9]}$ and was intrinsically designed and described by Matzinger within her famous danger theory. ${ }^{[10,11]}$ Whilst infectious tissue injury is associated with the presence of pathogen-associated molecular patterns (PAMPs) ${ }^{[12]}$ non-pathogen-mediated injury leads to the induction of so-called damage-associated molecular patterns, the DAMPs, as first described by us in 2003 . Notably, tissue-damaging infectious pathogens may even induce DAMPs that finally trigger a vigorous anti-pathogen innate immune response [Figure 2]. ${ }^{[13,14]}$ DAMPs, like PAMPs sensed by pattern recognition receptors (PRRs) such as Toll-like receptors (TLRs) and NOD-like receptors (NLRs), include the prototypic high-mobility group box 1 (HMGB1), heat shock proteins (HSPs), oxidized/minimally modified low-density lipoproteins (oxLDL/mmLDL), as well as endogenous DNA and RNA released from dying cells. ${ }^{[15-17]}$

Of note, the development of infectious and sterile inflammation, and also inflammation-mediated atherosclerosis and fibrosis is promoted - though not exclusively - by the function of inflammasomes, the two most extensively studied being the NLR-containing pyrin domain 3 (NLRP3) and the absent in melanoma 2 (AIM2) inflammasome. The characteristic function of these "molecular machines" of the innate immune system is to secrete interleukin-1 beta (IL-1 $\beta$ ) and IL-18 that mature from their proforms to bioactive cytokines through proteolytic cleavage by caspase-1..$^{[18-21]}$

Modern notions hold that full function of the NLRP3 inflammasome is a two-step process. The first step, the priming step, consists of stimulation of PRRs such as TLRs and leads, via transcriptional processes, to the up-regulation of NLRP3 and expression of pro-IL-1 $\beta$ and pro-IL-18 in the cytosol. The activation step is distinct from this initial priming step and reportedly mediated by various mechanistic pathways. Certain DAMPs such as reactive oxygen species (ROS)-induced oxidized proteins or extracellular adenosine triphosphate (eATP), uric acid, and nucleic acids (endogenous DNA, RNA) known to be released from damaged or dying cells appear to play a critical role in the activation of the NLRP3 inflammasome, with the double-stranded RNA-dependent protein kinase (PKR) also being shown 


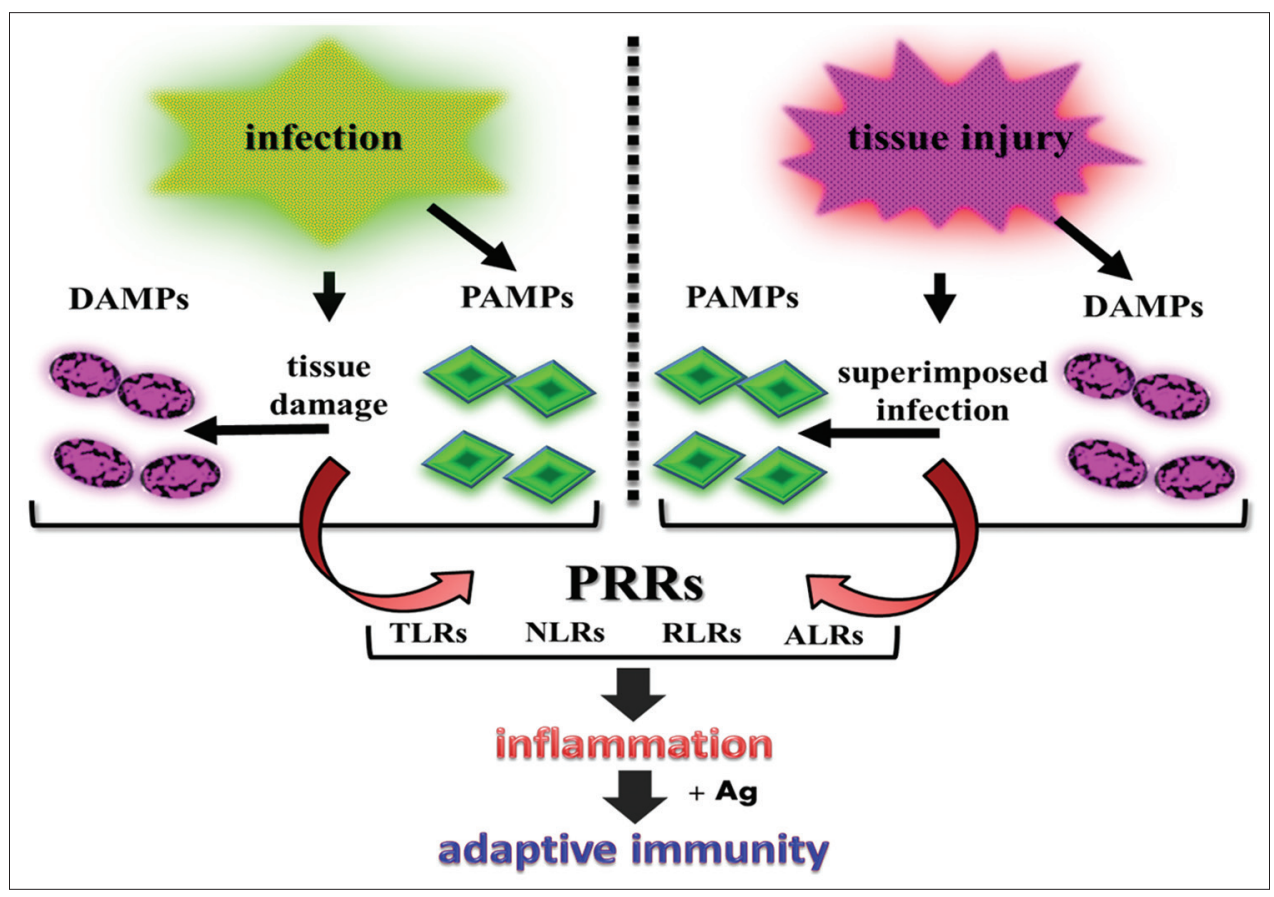

Figure 2: Schematic illustration of mutual generation of PAMPs and DAMPs during pathogen-mediated and non-pathogen-mediated tissue injury. Tissue damaging infectious pathogens may induce DAMPs that finally trigger a vigorous anti-pathogen inflammatory response; conversely, tissue primarily damaged by non-infectious agents is prone to get contaminated with pathogens that may lead to a life-threatening overshooting inflammatory response. (Ag, antigen; ALRs, AIM2-like receptors; NLRs, nucleotide-binding oligomerization domain-like receptors; PRRs, pattern recognition receptors; RLRs, RIG-I-like receptors; TLRs, Toll-like receptors)

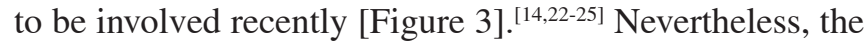
exact activating mechanism is still elusive; probably, any, even the slightest intra- or extracellular alteration of the microenvironment may activate this inflammasome. ${ }^{[26,27]}$

\section{Innate immunity and atherosclerosis}

Atherosclerosis is a chronic inflammatory disease in which both innate and adaptive (auto) immune mechanisms are involved [Figure 4]. ${ }^{[16,28-31]}$ The atherosclerotic plaque is characterized by an accumulation of lipids in the artery wall, together with infiltration of immune cells such as macrophages, mast cells, and $\mathrm{T}$ cells, and the formation of a fibrous cap composed mostly of collagen by vascular smooth muscle cells (VSMCs). The innate immune system of the normal artery represents the starting point of atherogenesis by responding to any inciting agent including oxidative, metabolic, mechanical, biotoxic, or infectious stress. PRR-bearing sessile cells such as endothelial cells (ECs) and VSMCs, exposed to injurious challenges, mount a primary inflammatory response in the arterial wall that is secondarily aggravated by the action of mobile cells such as macrophages, neutrophils, mast cells, and dendritic cells (DCs) infiltrating the subendothelial space. This process is associated with the transformation of quiescent contractile VSMCs that proliferate and migrate to the neointima where they produce ECM proteins leading to accumulation of fibrous tissue - a process that is pivotal for the onset and progression of atherosclerosis.

\section{DAMPs/PAMPs-PRRs engagement in atherosclerotic inflammation}

Numerous studies have identified oxidative stress-induced DAMPs as the major activators of vascular inflammation leading to atherosclerosis. ${ }^{[32]}$ Thus, atherogenesis starts with subendothelial retention and accumulation of circulating low-density lipoprotein (LDL) that undergoes various oxidative modifications. ${ }^{[29,30]}$ During the progression of atherosclerosis, most of these ROS-induced DAMPs are found in various forms of oxLDL and mmLDL. ${ }^{[16]}$ Further, oxidation-specific epitopes, for example, those derived from oxLDL, appear to play a prominent role by forming a distinct family of DAMPs consisting of various categories of oxidative reactions. Oxidation-specific epitopes that also possess antigenic properties operate as ligands for a common set of PRRs including natural IgM antibodies, their binding leading to activation of the complement cascade..$^{[16,33,34]}$

Other injury-induced DAMPs such as HSPs ${ }^{[35]}$ and HMGB1 known to bind to the receptor for advanced glycation end products (RAGE), TLR4 and TLR2 on vascular cells, ${ }^{[36,37]}$ are also involved in establishing a vascular inflammatory cascade contributing to atherogenesis. ${ }^{[38]}$ Of note, DAMPs such as HMGB1 and mmLDL were shown to participate in 


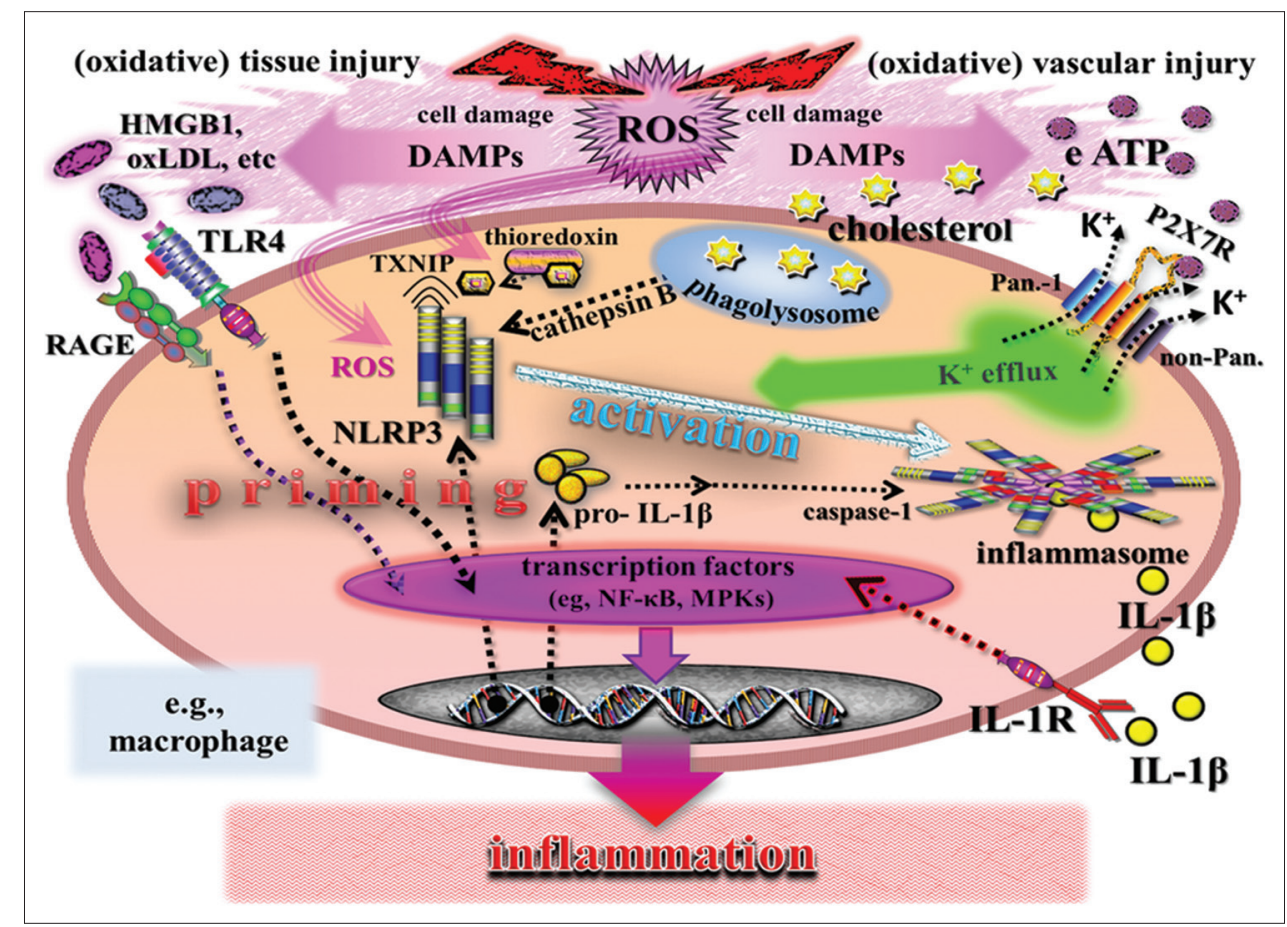

Figure 3: Oversimplified scenario model of (oxidative) injury-induced activation of the NLRP3 inflammasome. Priming through DAMPs such as HMGB1 induces ROS-dependent, transcription factor-mediated up-regulation of NLRP3 receptor (rather to be regarded as a sensor) and production of pro-IL-1 $\beta$ (and pro-IL-18 not shown in this figure). Finite activation of the inflammasome is provided by another class of DAMPs which are directly or indirectly sensed by NLRP3 via various mechanisms. Out of various proposed putative mechanisms, the figure selectively illustrates only: (I) activation via direct sensing of DAMPs such as mitochondrial ROS-modified thioreodoxin, the TXNIP and (II) activation via indirect sensing of DAMPs such as (1) cholesterol crystals which may drive NLRP3 activation through its internalization leading to phagolysosome destabilization associated with leakage of cathepsin B and (2) extracellular ATP which may activate NLRP3 by binding to the ionotropic $\mathrm{P} 2 \mathrm{X} 7$ receptor leading to ion fluxes such as $\mathrm{K}^{+}$efflux through the $\mathrm{P} 2 \mathrm{X} 7$ receptor and other ion hemichannels such as pannexin-1. Although the exact mechanisms are still unclear, activation of NLRP3 allows inflammasome complex formation and maturation of pro-IL-1 $\beta$ (and pro-IL-18) via caspases- 1 cleavage to secretion of bioactive IL-1 $\beta$ (and IL-18 not shown here). Then, these key cytokines, in an autocrine or paracrine manner, lead to receptor-triggered transcriptional pathways resulting in the production of further proinflammatory mediator substances to create full-scale tissue inflammation. (eATP, extracellular adenosine triphosphate; HMGB1, high mobility group box 1; MPKs, mitogen-activated protein kinases; NF- $\kappa B$, nuclear factor-kappaB; non-Pan., non-pannexin-1 hemichannels; P2X7R, P2X purinoceptor 7; Pan.-1, pannexin-1 hemichannel; oxLDL, oxidized low-density lipoproteins; RAGE, receptor of advanced glycation end products; ROS, reactive oxygen species; TLR4, Toll-like receptor 4; TXNIP, thioredoxin-interacting protein)

VSMC phenotype transformation, ${ }^{[39-41]}$ as HSP70 was found to increase ECM production by human VSMCs through up-regulation of transforming growth factor-beta1 (TGF- $\beta 1$ ) expression. ${ }^{[42]}$ These observations indicate a direct role of DAMPs in the establishment of neointima formation leading to arterial wall remodeling [Figure 4].

Besides DAMPs, a number of various PRRs including TLRs, NLRs, and RAGE were shown to mediate atherosclerotic inflammation and contribute to plaque formation. ${ }^{[43-46]}$ Of particular interest amongst those receptors is the lectin-like oxidized LDL receptor-1 (LOX-1) that was found to be expressed in ECs and VSMCs and to be highly up-regulated in atherosclerosis. ${ }^{[47]}$

The possibility that infectious agents via generation of PAMPs provoke relevant innate immune responses to arteries has been considered, but little evidence supports a primary impact, though contributory roles are possible.
Accordingly, a large number of infectious agents reportedly have been linked with an increased risk of vascular disease, including Chlamydia pneumonia, Porphyromonas gingivalis, Helicobacter pylori, influenza A virus, herpes virus, hepatitis $\mathrm{C}$ virus (HCV), cytomegalovirus (CMV), and human immunodeficiency virus. ${ }^{[48,49]}$

\section{Role of the NLRP3 inflammasome in atherogenesis}

Of note, the discovery of the inflammasome protein complex, located in both sessile and infiltrated vascular cells, has shed some more light on the mechanisms involved in mounting vascular inflammation involved in atherogenesis. ${ }^{[50]}$ In particular, studies on murine and human phagocytes and in vivo settings revealed that crystals of cholesterol - operating as DAMPs - activate the NLRP3 inflammasome required for atherogenesis. ${ }^{[51-53]}$ Remarkably, more recent investigations in NLRP3-deficient mice 


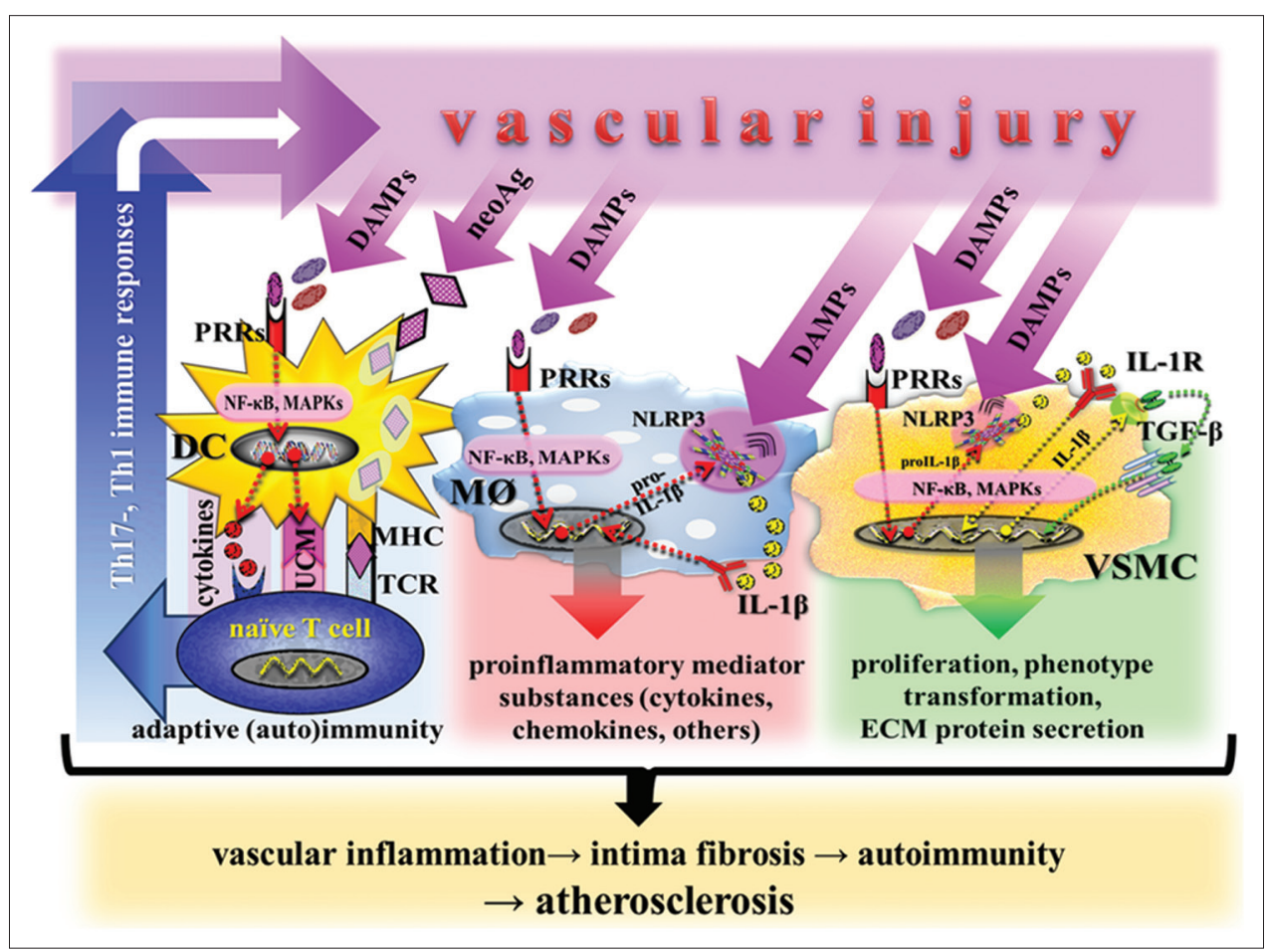

Figure 4: Scenario model of vascular injury-induced, innate and adaptive immune responses involved in atherogenesis. Vascular innate immune cells, here illustrated by PRR-bearing, NLRP3 inflammasome-expressing vascular smooth muscle cells, macrophages, and dendritic cells, are activated by various classes of DAMPs induced by vascular injuries. All three cell types exert different innate immune functions which orchestrate a network of processes leading to atherosclerosis: (1) activated smooth muscle cells, after recognition of DAMPs by PRRs (including NLRP3), contribute to development of intima fibrosis via proliferation and phenotype transformation able to secrete extracellular matrix proteins; (2) macrophages, via function of the NLRP3 inflammasome (e.g., activated by "priming" HMGB1 and "activating" cholesterol), contribute to creation of vessel wall inflammation; and (3) vascular dendritic cells, activated by recognition of DAMPs, engulf and process neoantigens (altered self-proteins) such as oxidation-specific epitopes, migrate to secondary lymphoid tissue, and present the peptide/MHC complex to naïve T cells. This leads to the initiation and induction of a specific adaptive Th17- and/or Th1 autoimmune response that, in terms of a vicious circle, may further aggravate the vascular injury. Note: Intracellular signaling pathways as sketched in the macrophage and the smooth muscle cell are illustrated in more detail in Figures 3 and 5. [DC, dendritic cell; ECM, extracellular matrix; IL-1R, interleukin-1 receptor; MØ, macrophage; MAPKs, mitogen-activated protein kinases; MHC, major histocompatibility complex; neoAg, neoantigens (altered-self antigens); NF-кB, nuclear factor-kappaB; NLRP3, NLR-containing pyrin domain 3; PRRs, pattern recognition receptors; TCR, T cell receptor; TGF- $\beta$, transforming growth factor-beta; UCM, up-regulation of costimulatory molecules; VSMC, vascular smooth muscle cell]

provided evidence even indicating that the NLRP3 inflammasome plays a crucial, non-redundant role in vascular damage-mediated neointima formation. ${ }^{[54]}$ Activation of the NLRP3 inflammasome in these settings is not quite clear. Of interest, however, are studies suggesting that oxidative stress - in its own or via induction of oxLDL - may operate as the "priming" DAMP in the early course of NLRP3 activation [Figures 3 and 4]. ${ }^{[33-56]}$

\section{Interplay between innate immunity and adaptive immunity in atherogenesis}

Adaptive immunity is not a prerequisite for atherogenesis, but its presence profoundly affects lesion formation and, on balance, is proatherogenic. Indeed, extensive data now support the notion that $\mathrm{T}$ cells, mainly Th1 cells in conjunction with interferon-gamma (IFN- $\gamma$ ), mediate proinflammatory and proatherogenic immune responses. ${ }^{[31]}$
Current notions hold that immunostimulatory DCs in the arterial wall, activated after recognition of DAMPs through PRRs, engulf and process stress/injury-induced neoantigens in terms of altered/modified self-proteins generated in early atherosclerotic lesions (or systemically), such as the oxidatively modified apolipoprotein B-100 component of LDL, HSPs, and others. The vascular autostimulatory DCs, then, present these altered self-proteins as peptide/major histocompatibility complex (MHC) complexes to naïve T cells in secondary lymphoid tissues, leading to $T$ cell clonal expansion and differentiation into effector Th1 cells, probably also Th17 cells. ${ }^{[29,31]}$ The effector $\mathrm{T}$ cells migrate into arterial lesions where they cause further vascular injury leading to induction of DAMPs that again initiate proinflammatory and/or profibrotic innate immune pathways (a vicious circle) [Figure 4].

However, the adaptive autoimmune response, in particular, during the early phases of atherogenesis, can also be 
atheroprotective as reflected, for example, by the generation of regulatory T cells (Tregs) that inhibit the activity of autoreactive Th1 effector $T$ cells by release of anti-inflammatory cytokines such as IL-10 and TGF- $\beta$ as well as production of protective antibodies. For example, many IgG antibodies to oxLDL inhibit the uptake of oxLDL by macrophages, at least in culture, suggesting that they should inhibit atherogenesis. As the disease progresses, this control is gradually lost and the immune responses toward plaque-associated neoantigens switch toward activation of Th1 or Th17 effector T cells and release of proinflammatory cytokines such as IFN- $\gamma$ and tumor necrosis factor-alpha as well as profibrotic IL-17. ${ }^{[31,57]}$

\section{Innate immunity and fibrosis}

Normal injury-induced, innate immune-mediated tissue repair can evolve into a progressively irreversible fibrotic response if the tissue injury is severe or repetitively chronic, or if the innate immune response becomes uncontrolled and exaggerated. "Fibrogenic" injury to tissues and organs can result from various inciting factors including chronic autoimmune responses, persistent infections, recurrent exposure to toxins, irritants, and mechanical injury, for example, mediated by hypertension.

The type of innate immune cells heavily involved in the extensive tissue damage and tissue repair is the fibroblast which operates as a sentinel cell ${ }^{[58]}$ and can be derived from resident fibroblasts, from circulating fibrocytes, or by epithelial-mesenchymal transition (EMT). ${ }^{[59]}$ Persistently activated fibroblasts called myofibroblasts mediate the excessive secretion of collagen in chronically injured organs and tissues. Myofibroblasts are phenotypically characterized by increased $\alpha$-smooth muscle actin ( $\alpha$-SMA). The key molecule TGF- $\beta$, in concert with other profibrotic cytokines and downstream growth factors such as the connective tissue growth factor, can induce the full repertoire of fibrotic responses and plays a direct role in fibroblast proliferation/differentiation and deposition of ECM proteins. ${ }^{[60]}$ TGF- $\beta$ is ubiquitously expressed and produced by multiple cell types in three isoforms (TGF- $\beta 1,-2$, and -3) in mammals (T cells being its essential source), but is kept latent and bound mostly to ECM components by non-covalent association with its propeptide, the latency associated peptide (LAP). ${ }^{[61,62]}$ Thus, the activation of TGF- $\beta$, a crucial point of regulation in TGF- $\beta$ function, is primarily regulated by conversion of latent TGF- $\beta$ to active TGF- $\beta$ and involves proteolysis of LAP or conformation changes of the latent TGF- $\beta$ caused by several factors such as proteases, ROS, and integrins. In particular, binding of the ECM receptors integrin $\alpha v \beta 6$ and $\alpha v \beta 8$ to the integrin-binding domain of the LAP of TGF- $\beta 1$ (causing cleavage of LAP and release of mature TGF- $\beta$ peptide) represents a major mechanism of TGF- $\beta 1$ activation in vivo. ${ }^{[1-65]}$ Activated members of the TGF- $\beta$ family function through interaction with TGF- $\beta$ receptors (type I and type II) that elicit Smad-dependent and Smad-independent signaling pathways [Figure 5]. ${ }^{[6]}$

Another type of innate immune cells, the macrophage, always found in close proximity with collagen-producing myofibroblasts, also plays a key role in fibrosis indisputably. Obviously, damaged parenchymal cells, such as tubular cells in the kidney, produce inflammatory cytokines and chemokines that subsequently promote intense macrophage infiltration. Of note, however, depending on the cytokine microenvironment, a certain class of macrophages with an "alternative activation state," the M2 macrophages that are distinct from proinflammatory "classically activated macrophages" (the M1 macrophages), appears to predominantly operate as those profibrotic macrophages. ${ }^{[67]}$

\section{DAMPs/PAMPs-PRRs engagement in fibrotic inflammation}

The dominating cells involved in fibrogenesis, fibroblasts, fibroblast-like cells, M2 macrophages, and epithelial cells are equipped with various innate immune receptors. Although intense clinical studies and experimental investigations have just been started, growing evidence already suggests that PRRs such as TLR2, TLR3, TLR4, TLR9, and RAGE play a dominant role in fibrogenesis, for example, via augmentation of TGF- $\beta$ activity. ${ }^{[68-77]}$

Of high interest are recent studies on various models, indicating a role of DAMPs such as HMGB1 in initiating molecular and cellular processes leading to fibrogenesis. ${ }^{\text {[78-80] }}$ Further, in other lines of studies on murine fibrotic models, extracellular HSP70 and fibrinogen (interacting with TLR2 and TLR4 on renal fibroblasts) were shown to act as DAMPs exerting profibrotic properties. ${ }^{[81,82]}$

In analogy to DAMPs, PAMPs such as LPS have also been demonstrated to act as "profibrotic" molecules in chronic PRR-mediated innate immune responses. ${ }^{[83]}$ In addition, infections with double-stranded DNA (dsDNA) viruses such as CMV and BK polyomavirus infection have been shown to contribute to fibrogenesis, presumably via activation of fibroblasts through DNA receptors such as the gamma-interferon-inducible protein 16 (IFI16) receptor ${ }^{[84,85]}$ and/or AIM2 receptor. ${ }^{[86]}$

\section{Role of the NLRP3 inflammasome in fibrogenesis}

Recent studies on fibroblasts and different organs have convincingly demonstrated that the innate immune sensor NLRP3, mostly inflammasome dependent ${ }^{[87-89]}$ but also inflammasome independent, ${ }^{[00]}$ plays a crucial role in fibrogenesis and can orchestrate profibrotic innate immune responses under both infectious and sterile conditions. 


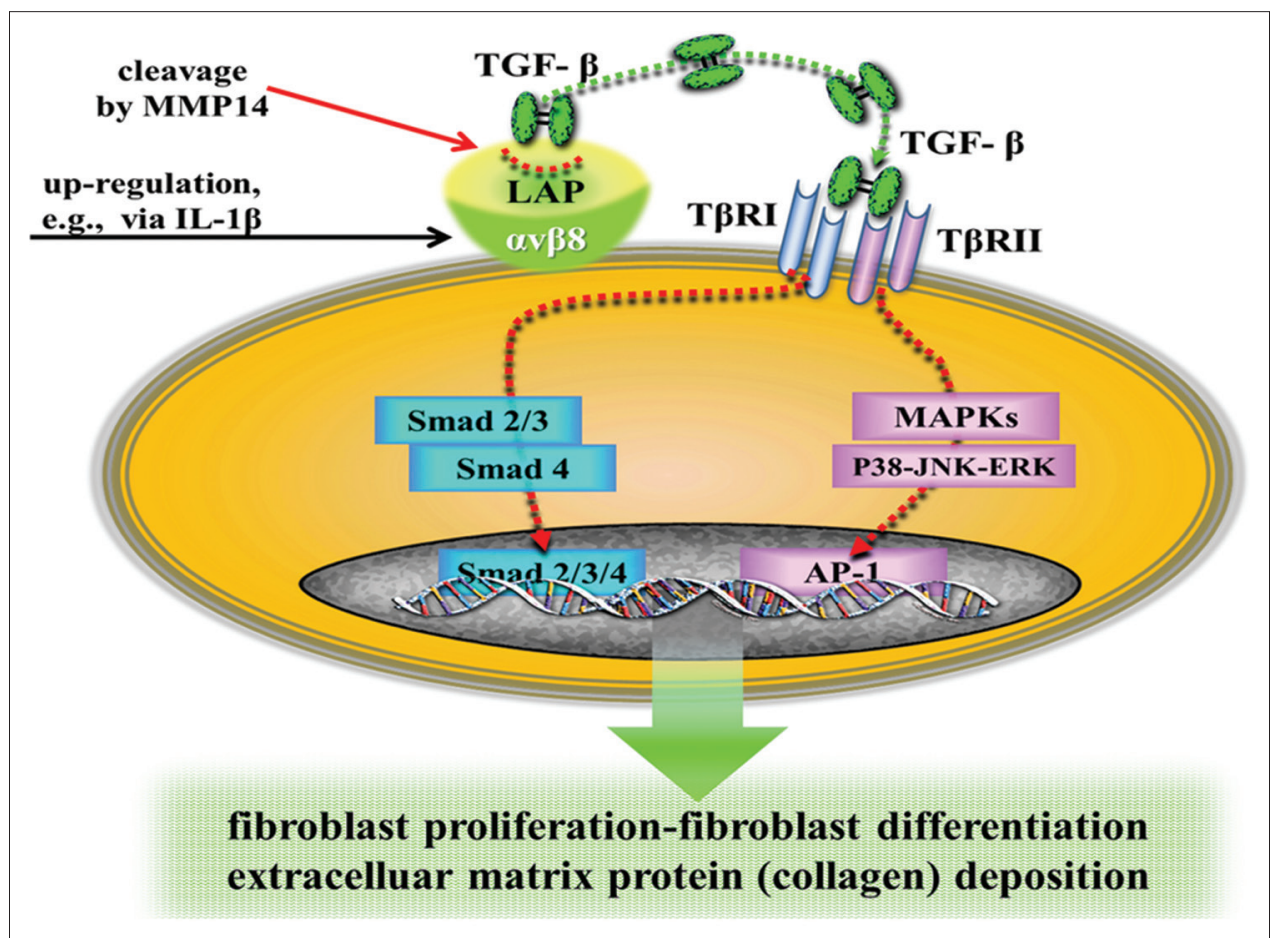

Figure 5: Schematic illustration of activation of transforming growth factor-beta and signaling pathways. Transforming growth factor-beta is kept latent and bound mostly to extracellular matrix components by non-covalent association with its propeptide, the latency associated peptide. Activation of the cytokine requires liberation of the TGF- $\beta$ dimer from the inactive latent complex with the LAP to active TGF- $\beta$, and involves proteolysis of LAP or conformation changes of the latent TGF- $\beta$ caused by several factors such as proteases or up-regulated integrins (e.g., $\alpha v \beta 8$ ). For example, binding of latent TGF- $\beta$ to $\alpha v \beta 8$ leads to the recruitment of a metalloprotease (MMP14) which causes cleavage of LAP and release of the active (mature) TGF- $\beta$. Activated members of the TGF- $\beta$ family function through interaction with TGF- $\beta$ receptors (type I and type II) that elicit Smad-dependent and Smad-independent signaling pathways, thereby inducing the full repertoire of fibrotic responses. [AP-1, activating protein-1; ERK, extracellular signal-regulated kinase; IL-1 $\beta$, interleukin-1beta; JNK, c-Jun NH (2)-terminal kinase; LAP, the latency associated peptide; MAPKs, mitogen-activated protein kinases; MMP14, metalloprotease 14; T $\beta$ RI/II, type I/type II transforming growth factor beta receptor; TGF- $\beta$, transforming growth factor beta]

In fact, it is now significantly apparent that the key products of the NLRP3 inflammasome, IL-1 $\beta$ and IL-18, exert profibrotic activities. ${ }^{[91-95]}$ Studies on the experimental fibrosis model of bleomycin (BLM)-induced lung injury revealed a role of the DAMPs uric acid and eATP that are released from damaged cells and activate the NLRP3 inflammasome leading to IL- $1 \beta$ production and lung fibrosis. In associated studies on this model, it was shown that IL-1 $\beta$ production is dependent on TLR2, TLR4, myeloid differentiation primary response gene 88 (MyD88), and interleukin-1 receptor type 1 (IL-1R1) pathways.

Of note, mechanistic studies on the BLM model in deficient mice revealed the existence of an early $I L-1 \beta$ $\rightarrow I L-23 \rightarrow I L-17$ (IL-17A) axis leading to inflammation and fibrosis, probably via promotion of proliferation, transformation, and collagen synthesis of fibroblasts. ${ }^{[96-99]}$ Of note, recent studies lent support to the assumption that this axis operates upstream of the expression of TGF- $\beta$ in terms of IL-1 $\beta$-induced transcriptional activation of TGF- $\beta$, for example, via up-regulation of integrin $\alpha v \beta 8$ expression on the cell surface. Active TGF- $\beta$, in an auto-/ paracrine manner, then, binds to fibroblast TGF- $\beta$ receptors [Figures 5 and 6]. ${ }^{[100-102]}$

Further studies provided evidence indicating a role of IL-1 $\beta$ and IL-18, in synergy with IL-23, for the activation of gammadelta $(\gamma \delta)$ T cells (including human $\gamma \delta$ T cells), to secrete (early) proinflammatory IL-17A, that, in turn, promotes fibrogenesis. ${ }^{[97,103-106]}$ Besides $\gamma \delta \mathrm{T}$ cells, natural killer T (NKT) cells and certain populations of innate lymphoid cells - although less pronounced - have been shown to secrete proinflammatory IL-17A supposed to contribute to fibrogenesis. ${ }^{[107]}$ Receptor-triggered signaling pathways regulating IL-17 production by $\gamma \delta$ T cells (as also by $\mathrm{CD}^{+}{ }^{+} \mathrm{Th} 17$ cells, see below) were reportedly shown to include the transcription factors retinoic acid-related orphan receptor (ROR $\gamma \mathrm{t})$ and signal transducer and activator of transcription 3 (STAT3). ${ }^{[108-110]}$

\section{Interplay between innate immunity and adaptive (Th17) immunity in fibrogenesis}

It is increasingly becoming apparent that not only innate immune responses but also adaptive immune responses 


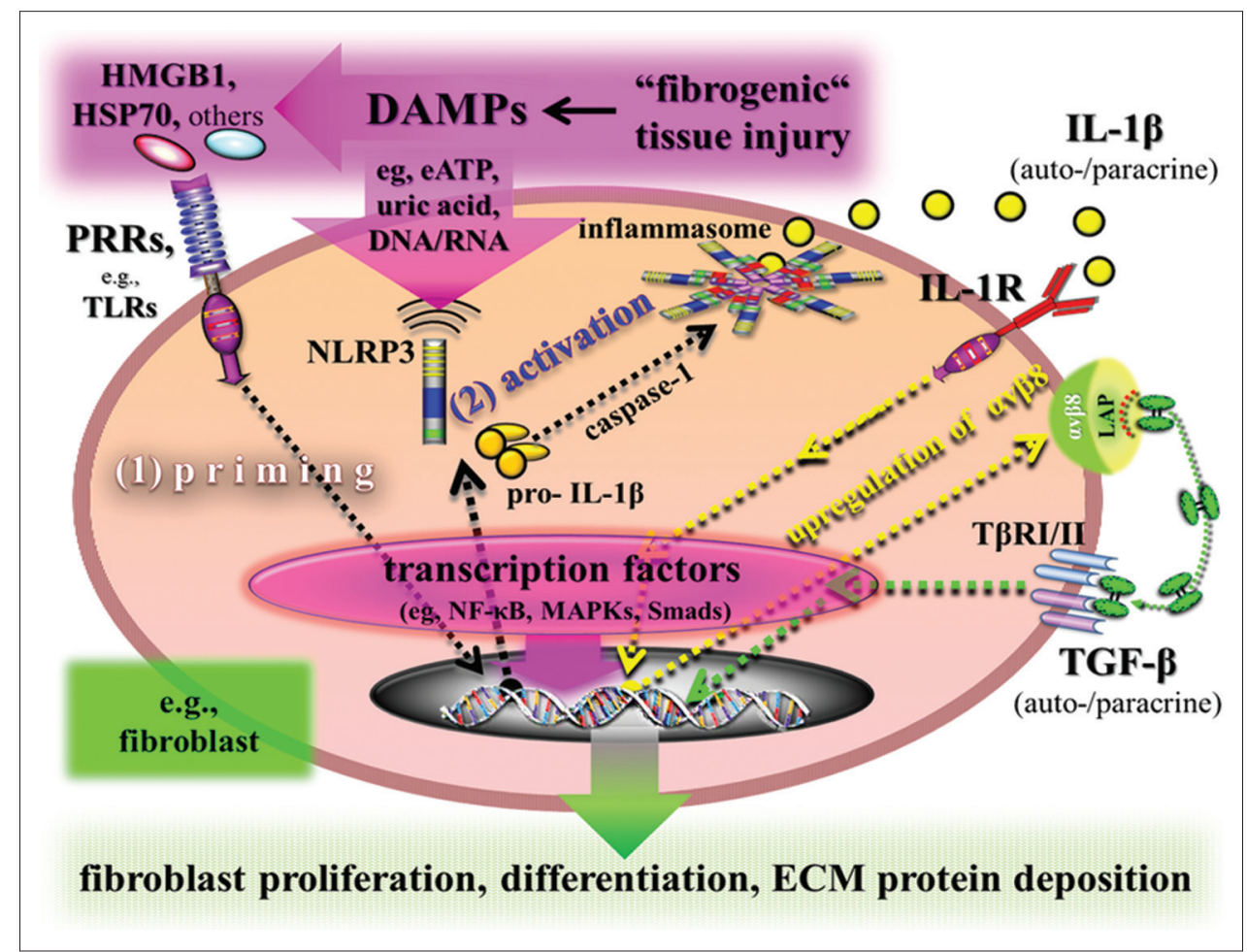

Figure 6: Scenario model: injury-induced, NLRP3 inflammasome-processed production of interleukin-1 beta leading, via autocrine/paracrine signaling, to activation of transforming growth factor- $\beta$. "Priming" DAMPs such as HMGB1 and "activating" DAMPs such as uric acid, extracellular ATP, or endogenous DNA/RNA (released from dying cells) induce assembly of the NLRP3 inflammasome, leading to production of IL-1 $\beta$ (and IL-18, not shown in the figure). IL- $1 \beta$ leads to transcription-mediated up-regulation of $\alpha \mathrm{v} \beta 8$ expression by fibroblasts, which results in increased conversion of latent to active TGF- $\beta$. Active TGF- $\beta$ is secreted from the cells and, in turn, in an autocrine/paracrine manner, binds to fibroblast TGF- $\beta$ receptors which trigger autocrine/paracrine signaling pathways, leading to transcription-mediated fibroblast proliferation and differentiation as well as collagen deposition. (eATP, extracellular adenosine triphosphate; HMGB1, high mobility group box 1; HSP70, heat shock protein 70; IL-1 $\beta$, interleukin-1beta; IL-1R, interleukin-1 receptor; LAP, the latency associated peptide; MAPKs, mitogen-activated protein kinases; NF-אB, nuclear factor-kappaB; NLRP3, NLR-containing pyrin domain 3; PRRs, pattern recognition receptors; T $\beta$ RI/II, type I/ type II transforming growth factor beta receptor; TLRs, Toll-like receptors; TGF- $\beta$, transforming growth factor beta)

participate in the differentiation and activation of fibroblasts leading to fibrosis. Depending on both the nature of antigenic stimulus and the injurious environment, various adaptive immune pathways have been described.

Most importantly, there is increasing evidence indicating a critical proinflammatory and profibrotic role of the adaptive Th17-type immune response. In fact, CD4+ Th17 cells, secreting (late) proinflammatory cytokines $I L-17 A$ and $I L-17 F$, are emerging as important drivers of fibrosis and were shown to contribute to the pathogenesis of many inflammatory and autoimmune diseases. ${ }^{[111,112]}$ The DC-dependent differentiation of Th17 cells is orchestrated by an intricate network of positive and negative polarizing cytokines and transcriptional regulators in T cells including STAT3-dependent ROR $\gamma t$ and ROR $\alpha$. In the center of this network, mitogen-activated protein kinases (MAPKs) (in particular, p38 $\alpha$ MAPK) signaling and inflammasome activation have emerged as critical pathways to program TH17 cell differentiation by integrating multiple instructive DAMP-induced signals in DCs. ${ }^{[113-119]}$
Accordingly, injury-induced, Th17-instructive DAMPs are sensed by PRRs on/in DCs which then drive Th17 cell differentiation by providing (auto) antigenic, costimulatory, and Th17-polarizing cytokine signals. The process to shape and stabilize Th17 development is mediated by (1) engulfment and processing by autostimulatory DCs of injury-induced neoantigens; (2) expression of selective costimulatory molecules enforced by CD40-CD40L ligation; (3) presence of Th17-polarizing, STAT3-activating cytokines, that is, IL-6, IL-23, and inflammasome-driven IL-1 $\beta / \mathrm{IL}-18$ mainly produced by DCs but also other innate immune cells; (4) TGF- $\beta 1$ and IL-21 produced by activated T cells; and finally (5) TGF- $\beta 1$ produced by Th17 cells themselves in an autocrine manner [Figure 7]. ${ }^{[107,113-122]}$

Taken together, also in view of the role of $\gamma \delta \mathrm{T}$ cells as mentioned above, these data identify the innate $I L-1 \beta \rightarrow I L-23 \rightarrow I L-17 A \leftrightarrow T G F-\beta 1$ cytokine axis as an important pathway in inflammation-mediated, innate/adaptive immunity-driven fibrogenesis. 


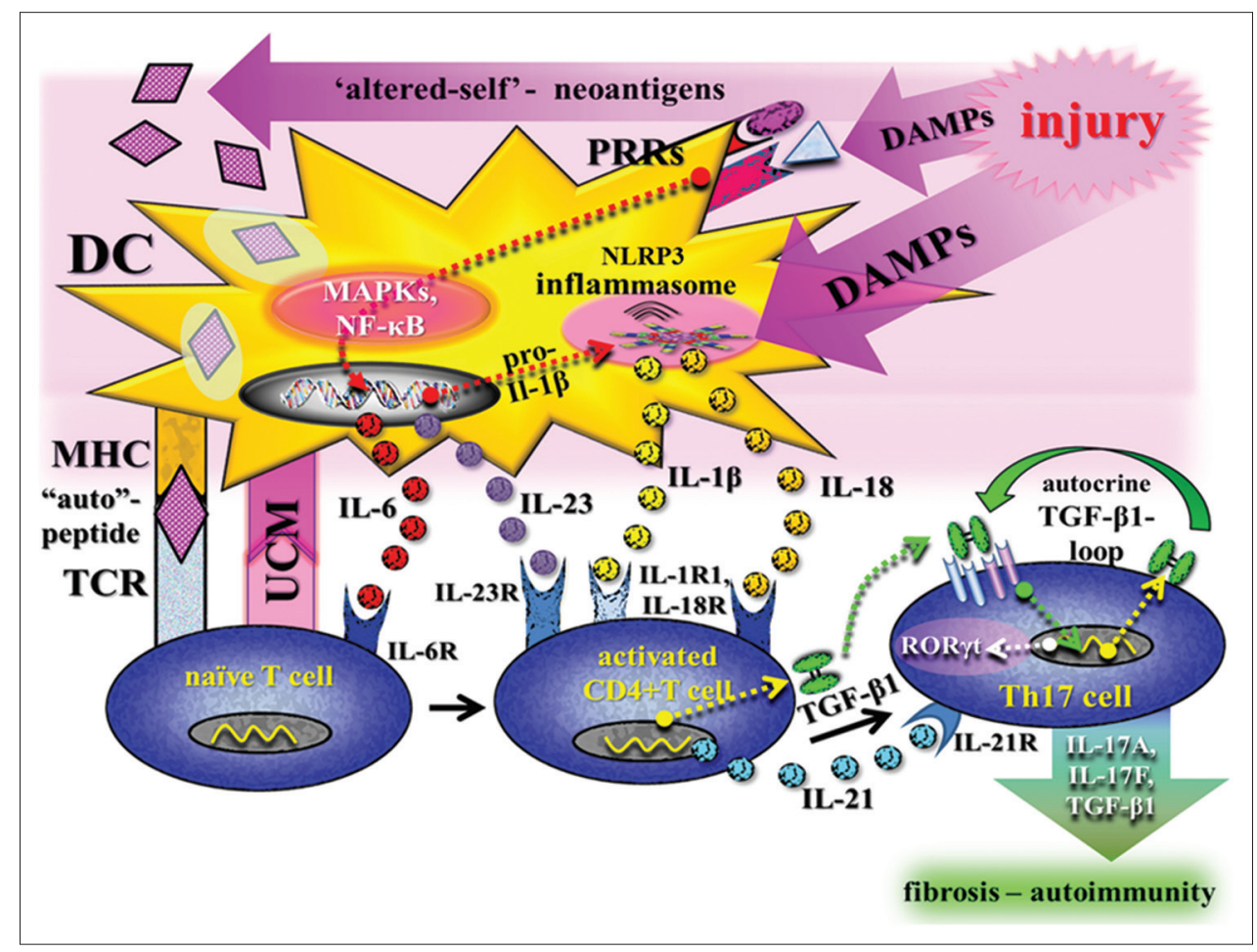

Figure 7: Scenario model: injury-induced, innate immunity-activated (Th17) autoimmunity leading to fibrosis via establishment of an "IL-1 $\beta \rightarrow I L-23 \rightarrow I L-17 A \leftrightarrow T G F-\beta 1$ cytokine axis." Injury-induced, Th17-instructive DAMPs are sensed by PRRs on/in DCs, which then drive Th17 cell differentiation by providing (auto) antigenic, costimulatory, and Th17-polarizing cytokine signals. The process to shape and stabilize Th17 development is further promoted by (1) IL-23 and NLRP3 inflammasome-driven IL-1 $\beta /$ IL-18 mainly produced by DCs (as shown in this figure), but also other innate immune cells; (2) TGF- $\beta$ and IL-21 produced by activated CD4+ T cells; and finally (3) TGF- $\beta$ produced by Th17 cells themselves in an autocrine manner. This scenario, as reflected by the "IL-1 $\beta \rightarrow I L-23 \rightarrow I L-17 A \leftrightarrow T G F-\beta 1$ cytokine axis," represents an important pathway in inflammation-mediated, innate/adaptive immunity-driven fibrogenesis. (DC, dendritic cell; ECM, extracellular matrix; IL, interleukin; IL-R, interleukin receptor; MAPKs, mitogen-activated protein kinases; MHC, major histocompatibility complex; NF-אB, nuclear factor-kappaB; NLRP3, NLR-containing pyrin domain 3; PRRs, pattern recognition receptors; TCR, T cell receptor; TGF- $\beta 1$, transforming growth factor-beta 1 ; UCM, up-regulation of costimulatory molecules)

In addition to Th17-type responses, Th2-type immunity is also a potent key driver of progressive fibrosis. As reviewed, ${ }^{[111]} \mathrm{Th} 2$ responses are defined by the production of IL-4, IL-5, and IL-13, while IL-13 has emerged as a dominant profibrotic cytokine that (independently of TGF- $\beta$ ) has been shown to mediate fibrotic tissue remodeling in several experimental and natural models of fibrosis. This suggests that unlike IL-17A but like TGF- $\beta$, IL-13 exerts direct fibrotic activity. ${ }^{[123,124]}$ Interestingly, in contrast to Th17- and Th2-type adaptive responses, Th1-type immunity has been demonstrated to convey antifibrotic activity, whereas Tregs were found to either suppress or promote fibrosis. ${ }^{[11]}$

\section{Allograft injury-induced, innate immunity- mediated chronic allograft dysfunction}

There are multiple injuries to an allograft which, via induction of innate immune pathways, may lead to CAD [Table 1]. ${ }^{[125]}$

The nature of injuries varies, appears to be partially organ specific, and includes causative factors such as allo-
Table 1: Causes of allograft injury

\begin{tabular}{lll}
\hline $\begin{array}{l}\text { Causes of allograft } \\
\text { injury }\end{array}$ & $\begin{array}{l}\text { Acute/subacute } \\
\text { clinically manifest, } \\
\text { subclinical injuries }\end{array}$ & $\begin{array}{l}\text { Persistently, repetitively } \\
\text { chronic injuries }\end{array}$ \\
\hline $\begin{array}{l}\text { Nonimmune } \\
\text { (mechanical, metabolic, } \\
\text { organotoxic)-mediated } \\
\text { injuries }\end{array}$ & $\begin{array}{l}\text { Donor brain death, } \\
\text { postischemic } \\
\text { reperfusion injury }\end{array}$ & $\begin{array}{l}\text { Donor senescence, } \\
\text { hypertension, } \\
\text { hyperlipidemia, } \\
\text { hyperglycemia, } \\
\text { organotoxic agents } \\
\text { Cellular and/or } \\
\text { antibody-mediated } \\
\text { allo-/isoimmune } \\
\text { (Th1-/Th17-mediated) } \\
\text { injuries }\end{array}$ \\
$\begin{array}{l}\text { Infection-mediated } \\
\text { injuries }\end{array}$ & $\begin{array}{l}\text { Cellular and/or } \\
\text { antibody-mediated } \\
\text { rejection episodes } \\
\text { Viral, bacterial, } \\
\text { fungal infections }\end{array}$ & $\begin{array}{l}\text { Viral infections, } \\
\text { e.g., cytomegalovirus } \\
\text { BK polyoma virus }\end{array}$ \\
\hline
\end{tabular}

immune and isoimmune responses, nonimmune-mediated conditions (mechanical, metabolic, and oxidative stress), as well as pathogen-mediated insults. Transplant clinicians used to interpret those injuries as risk factors of CAD. Accordingly, acute risk factors, divided into antigen-dependent and antigen-independent factors, have been identified, such 
as injuries mediated by donor brain death, postischemic reperfusion injury (IRI), acute rejection episodes, and infections. Defined chronic risk factors refer to persistently/ repetitively chronic allograft injuries such as subclinically ongoing alloimmune-mediated processes, in particular, alloantibody-mediated attacks, ${ }^{[126]}$ hypertension (mechanical injury), hyperlipidemia (metabolic stress), and administration of organotoxic immunosuppressive drugs such as nephrotoxic calcineurin inhibitors (CNIs).

It is apparent that allograft injury-induced CAD reflects a multifactorial event that, in case of severe cell-destroying insults, results from steadily ongoing loss of functioning parenchymal cells, and, in case of moderate sublytic insults, from accompanying, innate immunity-mediated inflammation. Of note, however, in both situations, injury-induced, innate immunity-mediated tissue repair mechanisms emerge which aggravate and accelerate the continuously deteriorating allograft function.

In fact, the histologically visible overshooting repair, that is, fibrosing processes such as intima fibrosis (alloatherosclerosis) and interstitial fibrosis (allofibrosis), contribute to $\mathrm{CAD}$ whereby the strength of their manifestation may depend on the organ transplanted. For example, alloatherosclerosis is more pronounced in cardiac allografts (coronary artery vasculopathy) ${ }^{[127]}$ whereas allofibrosis is more frequently observed in renal allografts [interstitial fibrosis associated with tubular atrophy (IFTA)] ${ }^{[128]}$ Probably, both histologically well-defined processes accelerate the progression of CAD as also recently discussed for chronic renal allograft dysfunction. ${ }^{[129]}$ In addition to these two "canonical" processes, there are typical organ-specific lesions associated with CAD such as the bronchiolitis obliterans syndrome following lung transplantation that also reflects an exaggerated repairing response of the donor's (uncontrolled) innate immune system to injury. ${ }^{[130]}$

In the following, by focusing on the parameters of clinically well-defined acute and chronic risk factors of CAD, some selected injury-induced innate immune processes, as comprehensively reviewed elsewhere, ${ }^{[131]}$ are briefly explored.

\section{Early antigen-independent allograft injury}

\section{Brain death}

A decade ago, early experiments on a rat model of brain death already revealed a strong influence of brain death (BD) condition on chronic graft dysfunction. ${ }^{[132]}$ Emerging evidence now indicates that BD conditions, associated with oxidative stress, ${ }^{[133,134]}$ activate the innate immune system that leads to development of an acute systemic auto-inflammatory syndrome. In fact, documented parameters involved in BD activated innate immune events include DAMPs, ${ }^{[135-137]}$ PRRs, and signaling molecules, ${ }^{[136,138,139]}$ complement fragments, ${ }^{[140]}$ cytokines such as IL-1 $\beta,{ }^{[134,141,142]}$ chemokines, ${ }^{[143]}$ and even matured DCs [Table 2]. ${ }^{[144,145]}$ On the other hand, in studies on a renal isograft model in rats, BD was shown to induce interstitial renal fibrosis. ${ }^{[146]}$ In these studies, fibrosis-inducing factors such as up-regulation of TGF- $\beta$ were discussed to be important in later progressive fibrotic changes that develop over time in kidney isografts.

\section{Postischemic reperfusion injury}

The pivotal influence of IRI on CAD is well known from an early clinical study of our group in kidney transplant patients. ${ }^{[7,8,131]}$ Production of ROS during IRI has been demonstrated in numerous experiments and also in a clinical study on human renal allografts. ${ }^{[147,148]}$

On the other hand, in studies in rats and mice, ${ }^{[146,149]}$ IRI was shown to induce severe renal fibrosis several weeks after the ROS-induced insult. In studies on a model of murine cardiac isografts, IRI was found to induce atherosclerosis. ${ }^{[150]}$ Moreover, a role of DAMPs and PRRs in IRI-mediated inflammation (including NLRP3 inflammasome-mediated inflammation) has been documented in numerous trials. In fact, there is no doubt that IRI, besides others, leads to the production of proinflammatory cytokines including IL-1 $\beta .{ }^{[151-154]}$

\section{Antigen-dependent allograft injuries}

\section{Th1 alloimmunity-mediated injury}

If we accept that any injury to an allograft may initiate innate immune events contributing to $\mathrm{CAD}$, one also has

Table 2: Association of brain death condition with parameters of innate immunity

\begin{tabular}{llc}
\hline $\begin{array}{l}\text { Parameters of innate } \\
\text { immunity }\end{array}$ & $\begin{array}{l}\text { "Innate" molecules } \\
\text { demonstrated in clin./exp. } \\
\text { studies on brain death }\end{array}$ & $\begin{array}{c}\text { References } \\
\text { (no.) }\end{array}$ \\
\hline Oxidative injury & ROS & 134,135 \\
Complement & C5b-9 & 141 \\
DAMPs & HMGB1 & 137 \\
& HSP70 & 136 \\
PRRs & TLR2 & 139 \\
Signaling molecules & MLR4 & 137,141 \\
& MAPKs & 140 \\
Cytokines & IL-1 $\beta$ & \\
& IL-6, TNF & 135 \\
Chemokine receptors & CxCR1, CxCR2 & 142,143 \\
Adhesion molecules & ICAM* & 144 \\
Dendritic cells & Mature DCs & 144 \\
\hline
\end{tabular}

*Demonstrated in experimental models of brain death only. Abbreviations: Clin.: Clinical; DAMPs: Damage-associated molecular patterns; DCs: Dendritic cells; Exp: Experimental; HMGB1: High mobility group box 1; HSP70: Heat shock protein 70; ICAM: Intracellular adhesion molecule 1; IL: Interleukin; JNK: c-Jun NH(2)-terminal kinase; MAPKs: Mitogen-associated protein kinases; PRRs: Pattern recognition receptors; ROS: Reactive oxygen species; TLR: Toll-like receptor; TNF: Tumor necrosis factor 
to include specific adaptive alloimmune-mediated injuries induced by acute and/or chronic, T cell-mediated and/or antibody-mediated processes. ${ }^{[155,156]}$ These alloimmunity-mediated inflammatory injuries, in terms of a feedback loop, can activate innate immune DCs which elicit again an alloimmune response leading to allograft injury (vicious circle) [Figure 8].

Classically, lytic or sublytic injuries, reportedly associated with production of ROS and operating in clinically manifest or subclinically ongoing acute allograft rejection episodes, ${ }^{[157-159]}$ are thought to be mediated predominantly by $\mathrm{CD}^{+} \mathrm{Th} 1$ cells, cytotoxic $\mathrm{CD} 8^{+} \mathrm{T}$ cells, and complement-binding alloantibodies. In particular, donor-specific antibodies (DSA)-mediated alloimmunity is currently regarded as an emerging concept of CAD. In fact, DSA cause profound changes not only in ECs of the allograft (micro) vasculature but also in allograft bronchioles, ${ }^{[160,161]}$ thereby fulfilling the prerequisite for induction of DAMPs to initiate fibrogenic innate immune processes. Of note, in the early phase of a Th1 alloimmune response, involvement of the Th17 cell lineage has recently been described to secrete IL-17 which appears to primarily facilitate the recruitment of leukocytes into the graft, thereby contributing to acute rejection (see below). ${ }^{[162,163]}$ Finally, there is already preliminary evidence in support of the notion that injury to donor ECs induced by non-MHC-, anti-EC isoantibodies or alloantibodies may contribute to innate immune-mediated alloatherosclerosis. ${ }^{[164,165]}$

Of note, the first experimental studies on various acute and chronic rejection models provided evidence supporting a role for adaptive alloimmune responses in activating innate immune responses via induction of DAMPs such as HMGB1 and HSPs, that is, agonists for TLR2/TLR4 and RAGE. ${ }^{[166-169]}$ In another line of experiments, DAMP (cytosolic DNA)-activated human DCs were found to be potent activators of the adaptive immune response. ${ }^{[170]}$ In support of this observation is a study on a model of cardiac allograft rejection demonstrating up-regulation of the apoptosis-related inflammasome. ${ }^{[171]}$ Moreover, recent experiments demonstrated that HMGB1 induces IL-17-producing T cells to mediate the early stage of cardiac allograft rejection in mice. ${ }^{[172]}$ Together, these new findings provide first clues that the NLRP3 inflammasome is already activated during alloimmune-mediated acute rejection episodes to start contributing to the establishment of the innate fibrogenic $I L-1 \beta \rightarrow I L-23 \rightarrow I L-17 A \leftrightarrow T G F-\beta 1$ cytokine axis.

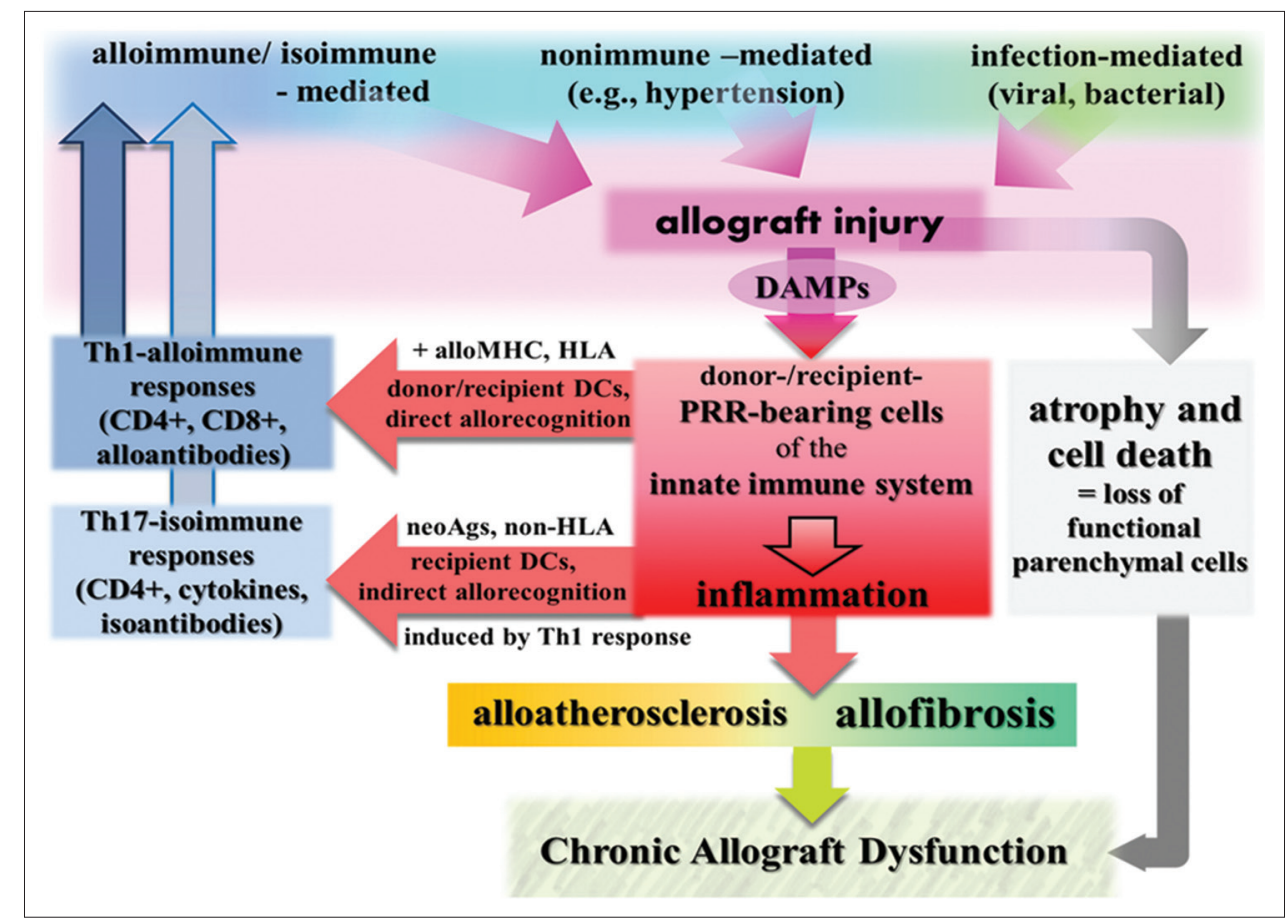

Figure 8: Scenario model: allograft injury-induced, innate immune-mediated chronic allograft dysfunction. Multiple acute and chronic allograft injuries, caused by allo- and isoimmune responses and/or nonimmune-mediated conditions (mechanical, metabolic, and oxidative stress) and/or infections, activate donor-derived innate immune cells (such as intragraft vascular cells, fibroblasts, and epithelial cells) and recipient-derived cells (such as graft-invading macrophages and leukocytes). The activated innate immune system responds to those various insults with allograft inflammation that, in turn, promotes development of alloatherosclerosis and allofibrosis. Together with injury-induced, cell death-associated atrophy, these innate immune events ultimately lead to chronic allograft dysfunction. Note the vicious circle of this scenario: Allograft injuries activate the innate immune system that elicits an adaptive allo- and isoimmune response leading to immune-mediated allograft injury that, in turn, activates the innate immune system again. (alloMHC, donor major histocompatibility complex; DC, dendritic cells; HLA, human leukocyte antigens; neoAgs, neoantigens) 
In addition, DAMPs such as oxidation-specific DAMPs and/or injury-induced DAMPs such as HMGB1 and HSPs demonstrated in acute and chronic rejection models ${ }^{[166-169]}$ may well act in terms of "NLRP3 inflammasome-priming" DAMPs that, in cooperation with cholesterol crystals or other "NLRP3 inflammasome-activating" DAMPs, are able to create an inflammatory milieu in the donor (micro) vasculature, contributing to alloatherogenesis, a scenario that has been discussed in quite a similar way elsewhere, ${ }^{[173]}$ and is emphasized in regard to native atherosclerosis in more recently published reports. ${ }^{[174,175]}$

Thus, although experimental and clinical data in support of such a concept are still sparse, one may discuss the possibility that acute and persistently/repetitively chronic adaptive alloimmune processes may promote the development of innate immune-mediated fibrotic processes as reflected by alloatherosclerosis and interstitial allofibrosis.

\section{Th17 isoimmunity-mediated injury}

The establishment of de novo Th17 autoimmunity/ autoreactivity that, besides Th1-type alloimmunity/alloreactivity, contributes to development of CAD is increasingly appreciated. ${ }^{[163,176]}$ From a recipient's view, this phenomenon occurring in the organ of another person may rather be called de novo isoimmunity. Increasing experimental and clinical evidence suggests that Th17 immunity, already known to contribute to development of both autoimmune diseases and acute allograft rejection, plays a critical role in CAD, ${ }^{[12,163,176]}$ but, notably, is resistant to CNI-based immunosuppression. ${ }^{[177]}$

Th17 immunity-mediated injury appears to be predominantly conveyed via secretion of cytokines including IL-17A, IL-17F, IL-21, and IL-22, which contribute to recruitment of immune cells, in particular, neutrophils, to sites of injury and lead to induction of DAMPs which, in turn, may activate innate immune cells such as DCs, fibroblasts, epithelial cells, and vascular cells. In addition, IL-17, in coordination with IL-21 and B cell activating factor of the TNF family (BAFF), promotes germinal center formation and influences B cells to produce pathogenic antibodies, ${ }^{[112,178]}$ a process that may add further injury to an allograft [Figure 8]. Most important, however, the secretion of IL-17 may lead to allofibrosis via contribution to the innate $I L-1 \beta \rightarrow I L-23 \rightarrow I L-17 A \leftrightarrow T G F-\beta 1$ cytokine axis mentioned above [Figure 7].

As reviewed ${ }^{[118]}$ PRRs expressed by DCs including TLRs and NLRs are essential to sense Th17-instructive DAMPs. These DAMPs, as demonstrated for HMGB1, may be induced by allograft injuries, in particular, by previous Th1 alloimmune response-mediated injury. ${ }^{[169,179]}$ Further, cytokine receptors and other immunomodulatory receptors also contribute to DC-mediated Th17 cell differentiation by affecting the production of Th17-polarizing cytokines. ${ }^{[118]}$ As also reviewed, ${ }^{[118]}$ activation of NLPR3-mediated in- flammasome has been shown to promote Th17 cell differentiation in autoimmune and inflammatory models. This is mechanistically believed to be linked to the requirement of NLRP 3 to promote IL- $1 \beta$ and IL-18 production from DCs for the potentiation of Th17 responses. These findings indicate that diverse recognition receptors in DCs triggered by certain selected DAMPs, including "NLRP3 inflammasome-activating" DAMPs such as adenosine released from injured graft cells, ${ }^{[180]}$ translate inflammatory mediators and environmental signals into proper Th17 cell generation.

Interestingly, Th17 immunity appears to be mainly directed against non-human leukocyte antigens (non-HLA) rather than against MHC/HLA alloantigens. In fact, a number of altered-self tissue antigens have emerged as targets of isoimmune responses after transplantation and vary depending on the transplanted organ. These isoantigens that are presented to naïve $\mathrm{T}$ cells by recipient $\mathrm{DCs}$ via the indirect pathway of allorecognition can be regarded as the result of intermolecular epitope spreading (in terms of allograft injury-induced exposure of "cryptic self-antigens") that was also demonstrated during chronic allograft rejection. ${ }^{[181]}$ These tissue-specific isoantigens reportedly involved in CAD include cardiac myosin, HSPs, vimentin, collagen type V, and K- $\alpha 1$ tubulin. ${ }^{[164,176]}$ Remarkably, clinical studies in recipients with cardiac allograft vasculopathy already demonstrated that Th17 cells specific to myosin, vimentin, Col-V, and $\mathrm{K}-\alpha 1 \mathrm{~T}$ are involved in CAD. ${ }^{[164,182]}$

\section{Chronic antigen-independent injuries}

\section{Hypertension}

In a state of chronic hypertension that itself is supposed to originate from primary innate/adaptive immune responses, ${ }^{[183]}$ the vessel wall is permanently injured, predominantly mediated by increased hemodynamic forces, that is, increased shear stress associated with oxidative stress and pathological stretch determined by luminal pressure. ${ }^{[184,185]}$ In turn, mechanical and oxidative stress in the vasculature may lead to the induction of DAMPs which initiate innate fibrogenic pathways and thereby promote atherogenesis. ${ }^{[131,183,186]}$

For example, in studies on in vitro stretching models of pulmonary epithelial cells and aortic smooth muscle cells, the stretch forces were shown to lead the DAMPs, HMGB1 and oxLDL. ${ }^{[187,188]}$ In addition, as shown in an experimental system consisting of rat arterial endothelial sheets exposed to tensile stretch stress, the expression of the endothelial DAMP, HSP70, was markedly up-regulated. ${ }^{[189]}$ In other lines of studies, the DAMP, HMGB1, was found to play a role in the pathogenesis of hypertension. ${ }^{[190,191]}$ On the other hand, hypertension/mechanical stress-induced PRRs such as TLR2, TLR4, and RAGE, known to recognize mechanical stress-induced DAMPs, have also been demonstrated to be involved in atherogenesis [Figure 4]. ${ }^{[131,192-195]}$ 
Of note, hypertension may also contribute to interstitial fibrogenesis as documented in experimental and clinical studies. ${ }^{[196-198]}$ Modern notions about potential hypertension-induced fibrogenesis include the discussion about mechanisms resulting in tissue hypoxia that, in turn, induced fibrosis. In renal fibrosis, for example, such mechanisms include hypertension-associated decreased renal blood flow due to increased vascular tone which is induced by angiotensin II that limits oxygen delivery. Notably, this process is associated with hypoxia and increases oxidative stress. Once fibrosis has developed, a vicious circle may be generated relating tubule-interstitial fibrosis to chronic hypoxia, which creates a self-sustaining mechanism that accelerates the fibrogenic process. ${ }^{[199]}$

\section{Dyslipidemia}

Lipid abnormalities are a common complication of transplantation, occurring in up to $60 \%$ of kidney transplanted patients. ${ }^{[200]}$ Following transplantation, lipid disturbances may show a different profile due to the various effects of immunosuppressive drugs on lipid metabolism. Accordingly, steroids, CNIs, and mammalian target of rapamycin (mTOR) inhibitors usually lead to quantitative and qualitative abnormalities of very low-density, low-density, and high-density lipoproteins. These proatherogenic lipid abnormalities (e.g., cholesterolemia), if suboptimally treated, may lead to cardiovascular complications as one of the leading causes of death in transplant recipients and, in addition, may promote $\mathrm{CAD}$ via contribution to alloatherosclerosis [Figures 3 and 4].

As outlined in more detail above, ${ }^{[16,28-47]}$ oxidized lipids such as oxLDL enriched in dyslipidemia may contribute to atherogenesis/alloatherogenesis via activation of innate immune pathways resulting in creation of arterial wall inflammation.

\section{Organotoxic drugs}

Organotoxic (e.g., nephrotoxic) and atherogenic immunosuppressive agents such as CNIs contribute to the development of CAD. There are numerous reports in the literature from experiments clearly showing an atherogenic effect of cyclosporine A (CsA), as indicated by induction of endothelial dysfunction, EC injury, and arteritis. As reviewed elsewhere, ${ }^{[201,202]}$ CsA can induce the generation of ROS (in particular, free hydroxyl radicals in kidneys of CsA-treated rats) and HSPs induced by ROS, respectively. In regard to CsA-mediated renal fibrosis, targeted studies revealed that the proximal tubular epithelial cells themselves are direct targets for CsA-induced injury. ${ }^{[203]}$ As a matter of fact, evidence was provided suggesting that CsA can cause an EMT-like event in human renal epithelial cells. ${ }^{[204]}$

On the other hand, there is accumulating evidence suggesting that CNI-induced chronic global injury to renal allografts activates cells of innate immunity (i.e., vascular cells, epithelial cells, and fibroblasts/myofibroblasts) via chronic oxidative stress. In this scenario, ROS-induced DAMPs such as HSPs may operate as endogenous ligands of PRR-bearing renal cells, a notion that has experimentally been confirmed. ${ }^{[205-207]}$

Taken together, and in view of these experimental data, one may discuss that long-term application of CNIs in kidney transplant patients accelerates the process of chronic allograft nephropathy via innate immune-mediated alloatherogenesis and allofibrogenesis.

\section{Infection-mediated allograft injuries}

Certain infectious diseases in transplant patients appear to be associated with CAD. In kidney transplant patients, this group preferentially includes urinary tract bacterial infections as well as nephropathy due to BK polyoma virus infection which activates the innate immune defense system through TLR3, contributing to intrarenal antiviral and anti-inflammatory responses. ${ }^{[208-210]}$ On the other hand, there is a considerable number of different infectious agents that have been linked with an increased risk of cardiovascular disease, including C. pneumonia, influenza A virus, $\mathrm{HCV}$, and $\mathrm{CMV} \cdot{ }^{[211,212]} \mathrm{As}$ documented, C. pneumonia, $\mathrm{CMV}$, and $\mathrm{HCV}$ infections have been identified as the risk factors for CAD. ${ }^{[213-215]}$

In regard to the underlying mechanisms of how a pathogen may contribute to alloatherogenesis or allofibrogenesis, a role for a direct pathogenic cytotoxic effect and an indirectly mediated effect via an anti-pathogen innate immune response eventually associated with collateral allograft damage, respectively, may be causative, as also discussed elsewhere. ${ }^{[210-212]}$ Another mechanism currently discussed refers to the possibility that infectious pathogens, via associated tissue injury, may lead to the induction of DAMPs which, in turn, result in an innate/adaptive immune response against host tissue, here the allograft [Figure 2]. ${ }^{[13,14]}$

\section{Outlook}

As already proposed by us two decades ago, ${ }^{[7,8]}$ convincing evidence has now accumulated in support of the notion that CAD results from multiple acute and/or persistently/ repetitively chronic injuries to an allograft. Such injuries arepredominantly caused by (1) an adaptive Th1 alloimmune response and, as increasingly appreciated, an adaptive Th17 isoimmune response, as well as (2) nonimmune antigen-independent attacks and (3) infection-mediated insults that may accelerate progression of dysfunction. Over time, exposure of an allograft to those various injurious attacks, in particular, when repeatedly occurring, leads - or at least contributes - to both progressive loss of functioning parenchymal cells and innate immunity/inflammation-mediated fibrosing processes of the (micro) vasculature and interstitium which, in turn, contribute to further loss of parenchymal 
cells. The NLRP3 inflammasome appears to play a dominant role in fibrogenesis, but other inflammasomes such as the AIM2 inflammasome may also contribute.

Emerging concepts of how to interfere with (1) those different injuries, (2) generation of DAMPs, and (3) subsequent PRR-mediated signaling pathways leading to fibrosis should guide us to innovative therapeutic approaches to tackle specifically this cardinal clinical problem in transplantation medicine. Certainly, various concepts can be considered. With respect to resistance of Th17 immunity to nephrotoxic CNIs, ${ }^{[177]}$ one example out of - quite admittedly - many potential strategies would refer to prophylactic treatment of infections in transplant patients (such as CMV or BK polyoma virus infection) with intravenous hyperimmune or standard immunoglobulin $\mathrm{G}$ preparations because, besides their antiviral properties, these biologicals exert immunosuppressive potency, ${ }^{[216]}$ induce Tregs via "Tregitopes" on DCs, ${ }^{[217]}$ and, importantly, have recently been shown to inhibit IL-17 production by Th17 cells involved in CAD. ${ }^{[218]}$

\section{REFERENCES}

1. Land W. Allograft injury mediated by reactive oxygen species: From conserved proteins of Drosophila to acute and chronic rejection of human transplants. Part III: Interaction of (oxidative) stress-induced heat shock proteins with Toll-like receptor-bearing cells of innate immunity and its consequences for the development of acute and chronic allograft rejection. Transplant Rev 2003;17:67-86.

2. Land WG. The role of postischemic reperfusion injury and other nonantigen-dependent inflammatory pathways in transplantation. Transplantation 2005;79:505-14.

3. Medzhitov R. Inflammation 2010: New adventures of an old flame. Cell 2010;140:771-6.

4. Racusen LC, Regele H. The pathology of chronic allograft dysfunction. Kidney Int Suppl 2010;119:S27-32.

5. Huibers M, De Jonge N, Van Kuik J, Koning ES, Van Wichen D, Dullens $\mathrm{H}$, et al. Intimal fibrosis in human cardiac allograft vasculopathy. Transpl Immunol 2011;25:124-32.

6. Todd JL, Palmer SM. Bronchiolitis obliterans syndrome: The final frontier for lung transplantation. Chest 2011;140:502-8.

7. Land W, Schneeberger H, Schleibner S, Illner WD, Abendroth D, Rutili G, et al. The beneficial effect of human recombinant superoxide dismutase on acute and chronic rejection events in recipients of cadaveric renal transplants. Transplantation 1994;57:211-7.

8. Land W, Messmer K. The impact of ischemia/reperfusion injury on specific and non-specific, early and late chronic events after organ transplantation. Transplant Rev 1996;10:108-27,236-53.

9. Land WG, Messmer K. The danger theory in view of the injury hypothesis: 20 years later. Front Immun 2012;3:349.

10. Matzinger P. Tolerance, danger, and the extended family. Annu Rev Immunol 1994;12:991-1045.

11. Matzinger P. The evolution of the danger theory. Interview by Lauren Constable, Commissioning Editor. Expert Rev Clin Immunol 2012;8:311-7.

Biomed J Vol. 36 No. 5

September - October 2013
12. Kumar H, Kawai T, Akira S. Pathogen recognition by the innate immune system. Int Rev Immunol 2011;30:16-34.

13. Xiang M, Fan J. Pattern recognition receptor-dependent mechanisms of acute lung injury. Mol Med 2010;16:69-82.

14. Jounai N, Kobiyama K, Takeshita F, Ishii KJ. Recognition of damage-associated molecular patterns related to nucleic acids during inflammation and vaccination. Front Cell Infect Microbiol 2012;2:168.

15. Chen GY, Nuñez G. Sterile inflammation: Sensing and reacting to damage. Nat Rev Immunol 2010;10:826-37.

16. Miller YI, Choi SH, Wiesner P, Fang L, Harkewicz R, Hartvigsen K, et al. Oxidation-specific epitopes are danger-associated molecular patterns recognized by pattern recognition receptors of innate immunity. Circ Res 2011;108:235-48.

17. Land WG. Oxidative injury-induced, damage-associated molecular pattern molecules and their pattern recognition receptors. In Innate Alloimmunity. Part II. Innate Immunity and Rejection. In: Land WG, editor. Ankara, Lengerich: Başkent University-Pabst Science Publishers; 2011. p. 229-322.

18. Horvath GL, Schrum JE, De Nardo CM, Latz E. Intracellular sensing of microbes and danger signals by the inflammasomes. Immunol Rev 2011;243:119-35.

19. Bauernfeind F, Ablasser A, Bartok E, Kim S, Schmid-Burgk J, Cavlar T, et al. Inflammasomes: Current understanding and open questions. Cell Mol Life Sci 2011;68:765-83.

20. Haneklaus M, O'Neill LA, Coll RC. Modulatory mechanisms controlling the NLRP3 inflammasome in inflammation: Recent developments. Curr Opin Immunol 2013;25:40-5.

21. Vladimer GI, Marty-Roix R, Ghosh S, Weng D, Lien E. Inflammasomes and host defenses against bacterial infections. Curr Opin Microbiol 2013;16:23-31.

22. Riteau N, Baron L, Villeret B, Guillou N, Savigny F, Ryffel B, et al. ATP release and purinergic signaling: A common pathway for particle-mediated inflammasome activation. Cell Death Dis 2012;3:e403.

23. Lu B, Nakamura T, Inouye K, Li J, Tang Y, Lundbäck P, et al. Novel role of PKR in inflammasome activation and HMGB1 release. Nature 2012;488:670-4.

24. Shimada K, Crother TR, Karlin J, Dagvadorj J, Chiba N, Chen S, et al. Oxidized mitochondrial DNA activates the NLRP3 inflammasome during apoptosis. Immunity 2012;36:401-14.

25. Haasken S, Sutterwala FS. Damage control: Management of cellular stress by the NLRP3 inflammasome. Eur J Immunol 2013;43;2003-5.

26. Rossol M, Pierer M, Raulien N, Quandt D, Meusch U, Rothe K, et al. Extracellular $\mathrm{Ca}(2+)$ is a danger signal activating the NLRP3 inflammasome through $\mathrm{G}$ protein-coupled calcium sensing receptors. Nat Commun 2012;3:1329.

27. Compan V, Baroja-Mazo A, López-Castejón G, Gomez AI, Martínez CM, Angosto D, et al. Cell volume regulation modulates NLRP3 inflammasome activation. Immunity 2012;37:487-500.

28. Packard RR, Lichtman AH, Libby P. Innate and adaptive immunity in atherosclerosis. Semin Immunopathol 2009;31:5-22.

29. Hansson GK, Hermansson A. The immune system in atherosclerosis. Nat Immunol 2011;12:204-12.

30. Libby P. Inflammation in atherosclerosis. Arterioscler Thromb Vasc 
Biol 2012;32:2045-51.

31. Lichtman AH, Binder CJ, Tsimikas S, Witztum JL. Adaptive immunity in atherogenesis: New insights and therapeutic approaches. J Clin Invest 2013;123:27-36.

32. Land WG. Interaction of damage-associated molecular patterns and pathogen-associated molecular patterns with pattern recognition receptor-bearing vascular cells and myofibroblasts and its consequences for the development of chronic allograft dysfunction. In Innate Alloimmunity. Part II. Innate Immunity and Rejection. In: Land WG, editor. Ankara, Lengerich: Başkent University-Pabst Science Publishers; 2011. p. 518-65.

33. Weismann D, Binder CJ. The innate immune response to products of phospholipid peroxidation. Biochim Biophys Acta 2012;1818:2465-75.

34. Zhang M, Carroll MC. Natural IgM-mediated innate autoimmunity: A new target for early intervention of ischemia-reperfusion injury. Expert Opin Biol Ther 2007;7:1575-82.

35. Wick G, Knoflach M, Xu Q. Autoimmune and inflammatory mechanisms in atherosclerosis. Annu Rev Immunol 2004;22:361-403.

36. Harja E, Bu DX, Hudson BI, Chang JS, Shen X, Hallam K, et al. Vascular and inflammatory stresses mediate atherosclerosis via RAGE and its ligands in apoE-/- mice. J Clin Invest 2008;118:183-94.

37. Kanellakis P, Agrotis A, Kyaw TS, Koulis C, Ahrens I, Mori S, et al. High-mobility group box protein 1 neutralization reduces development of diet-induced atherosclerosis in apolipoprotein edeficient mice. Arterioscler Thromb Vasc Biol 2011;31:313-9.

38. Andrassy M, Volz HC, Schuessler A, Gitsioudis G, Hofmann N, Laohachewin D, et al. HMGB1 is associated with atherosclerotic plaque composition and burden in patients with stable coronary artery disease. PLoS One 2012; 7:e52081.

39. Porto A, Palumbo R, Pieroni M, Aprigliano G, Chiesa R, Sanvito F, et al. Smooth muscle cells in human atherosclerotic plaques secrete and proliferate in response to high mobility group box 1 protein. FASEB J 2006;20:2565-6.

40. Karagiannis GS, Weile J, Bader GD, Minta J. Integrative pathway dissection of molecular mechanisms of moxLDL-induced vascular smooth muscle phenotype transformation. BMC Cardiovasc Disord 2013;13:4.

41. Yu W, Liu-Bryan R, Stevens S, Damanahalli JK, Terkeltaub R. RAGE signalling mediates post-injury arterial neointima formation by suppression of liver kinase B1 and AMPK activity. Atherosclerosis 2012;222:417-25.

42. González-Ramos M, Calleros L, López-Ongil S, Raoch V, Griera M, Rodríguez-Puyol M, et al. HSP70 increases extracellular matrix production by human vascular smooth muscle through TGF- $\beta 1$ up-regulation. Int J Biochem Cell Biol 2013;45:232-42.

43. Curtiss LK, Tobias PS. Emerging role of toll-like receptors in atherosclerosis. J Lipid Res 2009;50:5340-5.

44. Opitz B, Eitel J, Meixenberger K, Suttorp N. Role of Toll-like receptors, NOD-like receptors and RIG-I-like receptors in endothelial cells and systemic infections. Thromb Haemost 2009;102:1103-9.

45. Lundberg AM, Yan ZQ. Innate immune recognition receptors and damage-associated molecular patterns in plaque inflammation. Curr Opin Lipidol 2011;22:343-9.

46. Su X, Ao L, Shi Y, Johnson TR, Fullerton DA, Meng X. Oxidized low density lipoprotein induces bone morphogenetic protein-2 in coronary artery endothelial cells via Toll-like receptors 2 and 4. J Biol Chem 2011;286:12213-20.

47. Mehta JL, Khaidakov M, Hermonat PL, Mitra S, Wang X, Novelli G, et al. LOX-1: A new target for therapy for cardiovascular diseases. Cardiovasc Drugs Ther 2011;25:495-500.

48. Rosenfeld ME, Campbell LA. Pathogens and atherosclerosis: Update on the potential contribution of multiple infectious organisms to the pathogenesis of atherosclerosis. Thromb Haemost 2011;106:858-67.

49. Tufano A, Di Capua M, Coppola A, Conca P, Cimino E, Cerbone AM, et al. The infectious burden in atherothrombosis. Semin Thromb Hemost 2012;38:515-23.

50. Yin Y, Pastrana JL, Li X, Huang X, Mallilankaraman K, Choi ET, et al. Inflammasomes: Sensors of metabolic stresses for vascular inflammation. Front Biosci 2013;18:638-49.

51. Duewell P, Kono H, Rayner KJ, Sirois CM, Vladimer G, Bauernfeind FG, et al. NLRP3 inflammasomes are required for atherogenesis and activated by cholesterol crystals. Nature 2010;464:1357-61.

52. Rajamäki K, Lappalainen J, Oörni K, Välimäki E, Matikainen S, Kovanen PT, et al. Cholesterol crystals activate the NLRP3 inflammasome in human macrophages: A novel link between cholesterol metabolism and inflammation. PLoS One 2010;5:e11765.

53. Masters SL, Latz E, O’Neill LA. The inflammasome in atherosclerosis and type 2 diabetes. Sci Transl Med 2011;3:81ps17.

54. Schlaweck S, Zimmer S, Struck R, Bartok E, Werner N, Bauernfeind F, et al. Critical role of nucleotide-binding oligomerization domain-like receptor 3 in vascular repair. Biochem Biophys Res Commun 2011;411:627-31.

55. Bauernfeind F, Bartok E, Rieger A, Franchi L, Núñez G, Hornung V. Cutting edge: Reactive oxygen species inhibitors block priming, but not activation, of the NLRP3 inflammasome. J Immunol 2011;187:613-7.

56. Jiang $\mathrm{Y}$, Wang $\mathrm{M}$, Huang $\mathrm{K}$, Zhang $\mathrm{Z}$, Shao $\mathrm{N}$, Zhang $\mathrm{Y}$, et al. Oxidized low-density lipoprotein induces secretion of interleukin-1 $\beta$ by macrophages via reactive oxygen species-dependent NLRP3 inflammasome activation. Biochem Biophys Res Commun 2012;425:121-6.

57. Björkbacka H, Fredrikson GN, Nilsson J. Emerging biomarkers and intervention targets for immune-modulation of atherosclerosis-A review of the experimental evidence. Atherosclerosis 2013;227:9-17.

58. Smith RS, Smith TJ, Blieden TM, Phipps RP. Fibroblasts as sentinel cells. Synthesis of chemokines and regulation of inflammation. Am J Pathol 1997;151:317-22.

59. Lee K, Nelson CM. New insights into the regulation of epithelial-mesenchymal transition and tissue fibrosis. Int Rev Cell Mol Biol 2012;294:171-221.

60. Wynn TA. Cellular and molecular mechanisms of fibrosis. J Pathol 2008;214:199-210.

61. Annes JP, Munger JS, Rifkin DB. Making sense of latent TGFbeta activation. J Cell Sci 2003;116:217-24.

62. Nishimura SL. Integrin-mediated transforming growth factor-beta activation, a potential therapeutic target in fibrogenic disorders. Am J Pathol 2009; 175:1362-70.

63. Taylor AW. Review of the activation of TGF-beta in immunity. J Leukoc Biol 2009;85:29-33. 
64. Jain M, Rivera S, Monclus EA, Synenki L, Zirk A, Eisenbart J, et al. Mitochondrial reactive oxygen species regulate transforming growth factor- $\beta$ signaling. J Biol Chem 2013;288:770-7.

65. Henderson NC, Sheppard D. Integrin-mediated regulation of TGF $\beta$ in fibrosis. Biochim Biophys Acta 2013;1832:891-6.

66. Biernacka A, Dobaczewski M, Frangogiannis NG. TGF- $\beta$ signaling in fibrosis. Growth Factors 2011;29:196-202.

67. Wynn TA, Barron L. Macrophages: Master regulators of inflammation and fibrosis. Semin Liver Dis 2010;30:245-57.

68. Lafyatis R, Farina A. New insights into the mechanisms of innate immune receptor signalling in fibrosis. Open Rheumatol J 2012;6:72-9.

69. Pulskens WP, Rampanelli E, Teske GJ, Butter LM, Claessen N, Luirink IK, et al. TLR4 promotes fibrosis but attenuates tubular damage in progressive renal injury. J Am Soc Nephrol 2010;21:1299-308.

70. Guo J, Friedman SL. Toll-like receptor 4 signaling in liver injury and hepatic fibrogenesis. Fibrogenesis Tissue Repair 2010;3:21.

71. Braga TT, Correa-Costa M, Guise YF, Castoldi A, de Oliveira CD, Hyane MI, et al. MyD88 signaling pathway is involved in renal fibrosis by favoring a TH2 immune response and activating alternative M2 macrophages. Mol Med 2012;8:1231-9.

72. Booth AJ, Wood SC, Cornett AM, Dreffs AA, Lu G, Muro AF, et al. Recipient-derived EDA fibronectin promotes cardiac allograft fibrosis. J Pathol 2012;226:609-18.

73. Hogaboam CM, Trujillo G, Martinez FJ. Aberrant innate immune sensing leads to the rapid progression of idiopathic pulmonary fibrosis. Fibrogenesis Tissue Repair 2012;5 Suppl 1:S3.

74. Bhattacharyya S, Kelley K, Melichian DS, Tamaki Z, Fang F, $\mathrm{Su} \mathrm{Y}$, et al. Toll-like receptor 4 signaling augments transforming growth factor- $\beta$ responses: A novel mechanism for maintaining and amplifying fibrosis in scleroderma. Am J Pathol 2013;182:192-205.

75. Bai T, Lian LH, Wu YL, Wan Y, Nan Jx. Thymoquinone attenuates liver fibrosis via PI3K and TLR4 signaling pathways in activated hepatic stellate cells. Int Immunopharmacol 2013;15:275-81.

76. Kelly C, Canning P, Buchanan P, Williams MT, Brown VG, Gruenert DC, et al. Toll-like receptor 4 is not targeted to the lysosome in cystic fibrosis airway epithelial cells. Am J Physiol Lung Cell Mol Physiol 2013;304:L371-82.

77. Englert JM, Kliment CR, Ramsgaard L, Milutinovic PS, Crum L, Tobolewski JM, et al. Paradoxical function for the receptor for advanced glycation end products in mouse models of pulmonary fibrosis. Int J Clin Exp Pathol 2011;4:241-54.

78. Ge WS, Wu JX, Fan JG, Wang YJ, Chen YW. Inhibition of high-mobility group box 1 expression by siRNA in rat hepatic stellate cells. World J Gastroenterol 2011;17:4090-8.

79. Yin JP, Su ZL, Wang YM, Wang T, Tian SS, Xu XX, et al. Release of HMGB1 by LPS-treated cardiac fibroblasts and its contribution to the production of collagen type I and III. (English written abstract) Xi Bao Yu Fen Zi Mian Yi Xue Za Zhi 2012;28:785-8.

80. Lynch J, Nolan S, Slattery C, Feighery R, Ryan MP, McMorrow T. High-mobility group box protein 1: A novel mediator of inflammatory-induced renal epithelial-mesenchymal transition. Am J Nephrol 2010;32:590-602.

81. Cai WF, Zhang XW, Yan HM, Ma YG, Wang XX, Yan J, et al. Intracellular or extracellular heat shock protein 70 differentially regulates cardiac remodelling in pressure overload mice. Cardiovasc Res 2010;88:140-9.

Biomed J Vol. 36 No. 5

September - October 2013
82. Sörensen I, Susnik N, Inhester T, Degen JL, Melk A, Haller H, et al. Fibrinogen, acting as a mitogen for tubulointerstitial fibroblasts, promotes renal fibrosis. Kidney Int 2011;80:1035-44.

83. Aoyama T, Paik YH, Seki E. Toll-like receptor signaling and liver fibrosis. Gastroenterol Res Pract 2010;2010. pii: 192543.

84. Duan X, Ponomareva L, Veeranki S, Panchanathan R, Dickerson E, Choubey D. Differential roles for the interferon-inducible IFI16 and AIM2 innate immune sensors for cytosolic DNA in cellular senescence of human fibroblasts. Mol Cancer Res 2011;9:589-602.

85. Unterholzner L, Keating SE, Baran M, Horan KA, Jensen SB, Sharma S, et al. IFI16 is an innate immune sensor for intracellular DNA. Nat Immunol 2010;11:997-1004.

86. Bostanci N, Meier A, Guggenheim B, Belibasakis GN. Regulation of NLRP3 and AIM2 inflammasome gene expression levels in gingival fibroblasts by oral biofilms. Cell Immunol 2011;270:88-93 .

87. Artlett CM. The Role of the NLRP3 Inflammasome in Fibrosis Open Rheumatol J 2012;6:80-6.

88. Artlett CM, Sassi-Gaha S, Rieger JL, Boesteanu AC, Feghali-Bostwick CA, Katsikis PD. The inflammasome activating caspase 1 mediates fibrosis and myofibroblast differentiation in systemic sclerosis. Arthritis Rheum 2011;63:3563-74.

89. Kawaguchi M, Takahashi M, Hata T, Kashima Y, Usui F, Morimoto $\mathrm{H}$, et al. Inflammasome activation of cardiac fibroblasts is essential for myocardial ischemia/reperfusion injury. Circulation 2011;123:594-604

90. Wang W, Wang X, Chun J, Vilaysane A, Clark S, French G, et al. Inflammasome-independent NLRP3 augments TGF- $\beta$ signaling in kidney epithelium. J Immunol 2013;190:1239-49.

91. Chaudhuri V, Zhou L, Karasek M. Inflammatory cytokines induce the transformation of human dermal microvascular endothelial cells into myofibroblasts: A potential role in skin fibrogenesis. J Cutan Pathol 2007;34:146-53.

92. Fix C, Bingham K, Carver W. Effects of interleukin-18 on cardiac fibroblast function and gene expression. Cytokine 2011;53:19-28.

93. Postlethwaite AE, Raghow R, Stricklin GP, Poppleton H, Seyer JM, Kang AH. Modulation of fibroblast functions by interleukin 1: Increased steady-state accumulation of type I procollagen messenger RNAs and stimulation of other functions but not chemotaxis by human recombinant interleukin 1 alpha and beta. J Cell Biol 1988;106:311-8.

94. Gasse P, Riteau N, Charron S, Girre S, Fick L, Pétrilli V, et al. Uric acid is a danger signal activating NALP3 inflammasome in lung injury inflammation and fibrosis. Am J Respir Crit Care Med 2009;179:903-13.

95. Riteau N, Gasse P, Fauconnier L, Gombault A, Couegnat M, Fick L, et al. Extracellular ATP is a danger signal activating $\mathrm{P} 2 \mathrm{X} 7$ receptor in lung inflammation and fibrosis. Am J Respir Crit Care Med 2010;182:774-83.

96. Wilson MS, Madala SK, Ramalingam TR, Gochuico BR, Rosas IO, Cheever AW, et al. Bleomycin and IL-1beta-mediated pulmonary fibrosis is IL-17A dependent. J Exp Med 2010;207:535-52.

97. Gasse P, Riteau N, Vacher R, Michel ML, Fautrel A, di Padova F, et al. IL-1 and IL-23 mediate early IL-17A production in pulmonary inflammation leading to late fibrosis. PLoS One 2011;6:e23185.

98. Dong Z, Kang Q, Lei W, Zhong H, Tai W, Wang D. Effects of interleukin-17 on murine pulmonary fibroblast proliferation, 
transformation and collagen synthesis (English written abstract). Nan Fang Yi Ke Da Xue Xue Bao 2012;32:75-9.

99. Okamoto Y, Hasegawa M, Matsushita T, Hamaguchi Y, Huu DL, Iwakura Y, et al. Potential roles of interleukin-17A in the development of skin fibrosis in mice. Arthritis Rheum 2012;64:3726-35.

100. Aoki H, Ohnishi H, Hama K, Ishijima T, Satoh Y, Hanatsuka K, et al. Autocrine loop between TGF-beta1 and IL-1beta through Smad3- and ERK-dependent pathways in rat pancreatic stellate cells. Am J Physiol Cell Physiol 2006;290:C1100-8.

101. Markovics JA, Araya J, Cambier S, Somanath S, Gline S, Jablons D, et al. Interleukin-1beta induces increased transcriptional activation of the transforming growth factor-beta-activating integrin subunit beta8 through altering chromatin architecture. J Biol Chem 2011;286:36864-74.

102. Kitamura H, Cambier S, Somanath S, Barker T, Minagawa S, Markovics J, et al. Mouse and human lung fibroblasts regulate dendritic cell trafficking, airway inflammation, and fibrosis through integrin $\alpha v \beta 8$-mediated activation of TGF- $\beta$. J Clin Invest 2011;121:2863-75.

103. Ness-Schwickerath KJ, Jin C, Morita CT. Cytokine requirements for the differentiation and expansion of IL-17A- and IL-22-producing human Vgamma2Vdelta2 T cells. J Immunol 2010;184:7268-80.

104. Caccamo N, La Mendola C, Orlando V, Meraviglia S, Todaro M, Stassi G, et al. Differentiation, phenotype, and function of interleukin-17-producing human $\mathrm{V} \gamma 9 \mathrm{~V} \delta 2 \mathrm{~T}$ cells. Blood 2011;118:129-38.

105. Mills KH, Dungan LS, Jones SA, Harris J. The role of inflammasome-derived IL-1 in driving IL-17 responses. J Leukoc Biol 2013;93:489-97.

106. Peral de Castro C, Jones SA, Ní Cheallaigh C, Hearnden CA, Williams L, Winter J, et al. Autophagy regulates IL-23 secretion and innate T cell responses through effects on IL-1 secretion. J Immunol 2012;189:4144-53.

107. Sutton CE, Mielke LA, Mills KH. IL-17-producing $\gamma \delta$ T cells and innate lymphoid cells. Eur J Immunol 2012;42:2221-31.

108. Havenar-Daughton C, Li S, Benlagha K, Marie JC. Development and function of murine ROR $\gamma \mathrm{t}+\mathrm{iNKT}$ cells are under TGF- $\beta$ signaling control. Blood 2012;119:3486-94.

109. Ivanov II, McKenzie BS, Zhou L, Tadokoro CE, Lepelley A, Lafaille JJ, et al. The orphan nuclear receptor RORgammat directs the differentiation program of proinflammatory IL-17+T helper cells. Cell 2006;126:1121-33.

110. Sutton CE, Lalor SJ, Sweeney CM, Brereton CF, Lavelle EC, Mills KH. Interleukin-1 and IL-23 induce innate IL-17 production from gamma delta $\mathrm{T}$ Cells, amplifying Th17 responses and autoimmunity. Immunity 2009;31:331-41.

111. Wynn TA, Ramalingam TR. Mechanisms of fibrosis: Therapeutic translation for fibrotic disease. Nat Med 2012;18:1028-40.

112. Maddur MS, Miossec P, Kaveri SV, Bayry J. Th17 cells: Biology, pathogenesis of autoimmune and inflammatory diseases, and therapeutic strategies. Am J Pathol 2012;181:8-18.

113. Mangan PR, Harrington LE, O'Quinn DB, Helms WS, Bullard DC, Elson CO, et al. Transforming growth factor-beta induces development of the T (H) 17 lineage. Nature 2006;441:231-4.

114. Li MO, Flavell RA. TGF-beta: A master of all T cell trades. Cell 2008;134:392-404.

115. Manel N, Unutmaz D, Littman DR. The differentiation of human
$\mathrm{T}(\mathrm{H})-17$ cells requires transforming growth factor- and induction of the nuclear receptor RORt. Nat Immunol 2008;9:641-9.

116. Volpe E, Servant N, Zollinger R, Bogiatzi SI, Hupe P, Barillot E, et al. A critical function for transforming growth factor-, interleukin 23 and proinflammatory cytokines in driving and modulating human $\mathrm{T}(\mathrm{H})-17$ responses. Nat Immunol 2008;9:650-7.

117. Korn T, Bettelli E, Oukka M, Kuchroo VK. IL-17 and Th17 Cells. Annu Rev Immunol 2009;27:485-517.

118. Huang G, Wang Y, Chi H. Regulation of TH17 cell differentiation by innate immune signals. Cell Mol Immunol 2012;9:287-95.

119. Gutcher I, Donkor MK, Ma Q, Rudensky AY, Flavell RA, Li MO. Autocrine transforming growth factor- $\beta 1$ promotes in vivo Th 17 cell differentiation. Immunity 2011;34:396-408.

120. Sutton C, Brereton C, Keogh B, Mills KH, Lavelle EC. A crucial role for interleukin (IL)-1 in the induction of IL-17-producing $\mathrm{T}$ cells that mediate autoimmune encephalomyelitis. J Exp Med 2006;203:1685-91

121. Zielinski CE, Mele F, Aschenbrenner D, Jarrossay D, Ronchi F, Gattorno M, et al. Pathogen-induced human TH17 cells produce IFN- $\gamma$ or IL-10 and are regulated by IL-1 $\beta$. Nature 2012;484:514-8.

122. Jones SA, Mills KH, Harris J. Autophagy and inflammatory diseases. Immunol Cell Biol 2013;91:250-8.

123. Kuperman DA, Huang X, Koth LL, Chang GH, Dolganov GM, Zhu Z, et al. Direct effects of interleukin-13 on epithelial cells cause airway hyperreactivity and mucus overproduction in asthma. Nat Med 2002;8:885-9.

124. Lee JH, Kaminski N, Dolganov G, Grunig G, Koth L, Solomon C, et al. Interleukin-13 induces dramatically different transcriptional programs in three human airway cell types. Am J Respir Cell Mol Biol 2001;25:474-85.

125. Womer KL, Vella JP, Sayegh MH. Chronic allograft dysfunction: Mechanisms and new approaches to therapy. Semin Nephrol 2000;20:126-47.

126. Sis B, Mengel M, Haas M, Colvin RB, Halloran PF, Racusen LC, et al. Banff '09 meeting report: Antibody mediated graft deterioration and implementation of Banff working groups. Am J Transplant 2010;10:464-71.

127. Topilsky Y, Gandhi MJ, Hasin T, Voit LL, Raichlin E, Boilson BA, et al. Donor-specific antibodies to class II antigens are associated with accelerated cardiac allograft vasculopathy-a three-dimensional volumetric intravascular ultrasound study. Transplantation 2013;95:389-96.

128. Solez K, Colvin RB, Racusen LC, Haas M, Sis B, Mengel M, et al. Banff 07 classification of renal allograft pathology: Updates and future directions. Am J Transplant 2008;8:753-60.

129. Famulski KS, Reeve J, de Freitas DG, Kreepala C, Chang J, Halloran PF. Kidney transplants with progressing chronic diseases express high levels of acute kidney injury transcripts. Am J Transplant 2013;13:634-44.

130. Todd JL, Palmer SM. Bronchiolitis obliterans syndrome: The final frontier for lung transplantation. Chest 2011;140:502-8.

131. Land WG. Oxidative allograft injury and other acute and chronic risk factors for the development of chronic allograft dysfunction - revisited in light of innate immunity. In Innate Alloimmunity. Part II. Innate Immunity and Rejection. In: Land WG, editor. Ankara, Lengerich: Başkent University-Pabst Science Publishers; 2011. p. 566-86. 
132. Pratschke J, Wilhelm MJ, Laskowski I, Kusaka M, Beato F, Tullius SG, et al. Influence of donor brain death on chronic rejection of renal transplants in rats. J Am Soc Nephrol 2001;12:2474-81.

133. Kosieradzki M, Kuczynska J, Piwowarska J, Wegrowicz-Rebandel I, Kwiatkowski A, Lisik W, et al. Prognostic significance of free radicals: Mediated injury occurring in the kidney donor. Transplantation 2003;75:1221-7

134. Leber B, Stadlbauer V, Stiegler P, Stanzer S, Mayrhauser U, Koestenbauer S, et al. Effect of oxidative stress and endotoxin on human serum albumin in brain-dead organ donors. Transl Res 2012;159:487-96.

135. Arbogast H, Arbogast S, Fertmann J, Abendroth D, Illner WD, Land $\mathrm{W}$, et al. Expression of heat shock proteins in cadaveric human renal allografts- a role in activation of innate immunity? Transplantation 2002;74:266.

136. Krüger B, Krick S, Dhillon N, Lerner SM, Ames S, Bromberg JS, et al. Donor Toll-like receptor 4 contributes to ischemia and reperfusion injury following human kidney transplantation. Proc Natl Acad Sci USA 2009;106:3390-5.

137. Quiroga I, Salio M, Koo DD, Cerundolo L, Shepherd D, Cerundolo V, et al. Expression of MHC class I-related Chain B (MICB) molecules on renal transplant biopsies. Transplantation 2006;81:1196-203.

138. Rostron AJ, Cork DM, Avlonitis VS, Fisher AJ, Dark JH, Kirby JA. Contribution of Toll-like receptor activation to lung damage after donor brain death. Transplantation 2010;90:732-9.

139. Chen L, Xu D, Gao Y, Cui X, Du Z, Ding Q, et al. Effect of donor JNK signal transduction inhibition on transplant outcome in brain dead rat model. Inflammation 2012;35:122-9.

140. Damman J, Daha MR, van Son WJ, Leuvenink HG, Ploeg RJ, Seelen MA. Crosstalk between complement and Toll-like receptor activation in relation to donor brain death and renal ischemia-reperfusion injury. Am J Transplant 2011;11:660-9.

141. Takada M, Nadeau KC, Hancock WW, Mackenzie HS, Shaw GD, Waaga AM, et al. Effects of explosive brain death on cytokine activation of peripheral organs in the rat. Transplantation 1998;65:1533-42.

142. Kusaka M, Pratschke J, Wilhelm MJ, Ziai F, Zandi-Nejad K, Mackenzie HS, et al. Activation of inflammatory mediators in rat renal isografts by donor brain death. Transplantation 2000;69:405-1 .

143. Danobeitia JS, Sperger JM, Hanson MS, Park EE, Chlebeck PJ, Roenneburg DA, et al. Early activation of the inflammatory response in the liver of brain-dead non-human primates. J Surg Res 2012; 176:639-48.

144. Morariu AM, Martins PN, Leuvenink HG. Brain death and donor age synergistically accelerate the early immune response of allograft recipient (abstract\# 0155). Transpl Int 2007;20:47.

145. Velásquez-Lopera MM, Correa LA, García LF. Human spleen contains different subsets of dendritic cells and regulatory $\mathrm{T}$ lymphocytes. Clin Exp Immunol 2008;154:107-14.

146. Pratschke J, Wilhelm MJ, Laskowski I, Kusaka M, Beato F, Tullius SG, et al. Influence of donor brain death on chronic rejection of renal transplants in rats. J Am Soc Nephrol 2001;12:2474-81.

147. Fertmann J, Arbogast H, Hoffmann J, Land W. Generation of hydroxyl radical is increased after reperfusion of human cadaveric renal allografts. Transplantation 2002;74:393.

148. Land WG. Emerging role of innate immunity in organ transplantation:
Part I: Evolution of innate immunity and oxidative allograft injury. Transplant Rev (Orlando) 2012;26:60-72.

149. de Vries DK, Schaapherder AF, Reinders ME. Mesenchymal stromal cells in renal ischemia/reperfusion injury. Front Immunol 2012;3:162.

150. Furukawa Y, Libby P, Stinn JL, Becker G, Mitchell RN. Cold ischemia induces isograft arteriopathy, but does not augment allograft arteriopathy in non-immunosuppressed hosts. Am J Pathol 2002;160:1077-87.

151. Kaczorowski DJ, Tsung A, Billiar TR. Innate immune mechanisms in ischemia/reperfusion. Front Biosci 2009;1:91-8.

152. Zhai Y, Petrowsky H, Hong JC, Busuttil RW, Kupiec-Weglinski JW. Ischaemia-reperfusion injury in liver transplantation-from bench to bedside. Nat Rev Gastroenterol Hepatol 2013;10:79-89.

153. Iyer S, Pulskensc W, Sadler J, Butter LM, Teske GJ, Ulland TK, et al. Necrotic cells trigger a sterile inflammatory response through the Nlrp3 inflammasome. PNAS 2009;106:20388-93.

154. Land WG. Emerging role of innate immunity in organ transplantation part II: Potential of damage-associated molecular patterns to generate immunostimulatory dendritic cells. Transplant Rev (Orlando) 2012;26:73-87.

155. Halloran PF, de Freitas DG, Einecke G, Famulski KS, Hidalgo LG, MengeL M, et al. An integrated view of molecular changes, histopathology and outcomes in kidney transplants. Am J Transplant 2010;10:2223-30.

156. Matignon M, Muthukumar T, Seshan SV, Suthanthiran M, Hartono C. Concurrent acute cellular rejection is an independent risk factor for renal allograft failure in patients with C4d-positive antibody-mediated rejection. Transplantation 2012;94:603-11.

157. Sun K, Kiss E, Bedke J, Stojanovic T, Li Y, Gwinner W, et al. Role of xanthine oxidoreductase in experimental acute renal-allograft rejection. Transplantation 2004;77:1683-92.

158. Ott U, Aschoff A, Funfstuck R, Jirikowski G, Wolf G. DNA fragmentation in acute and chronic rejection after renal transplantation. Transplant Proc 2007;39:73-7.

159. Bhandary UV, Shirodkar B, Tse W, Hodgkinson AD, Demaine AG. A polymorphism of NADPH oxidase $\mathrm{p} 22$ phox is associated with reduced susceptibility to acute rejection in renal allograft recipients. Transpl Immunol 2011;25:16-9.

160. Drachenberg CB, Papadimitriou JC. Endothelial injury in renal antibody-mediated allograft rejection: A schematic view based on pathogenesis. Transplantation 2013;95:1073-83.

161. Lobo LJ, Aris RM, Schmitz J, Neuringer IP. Donor-specific antibodies are associated with antibody-mediated rejection, acute cellular rejection, bronchiolitis obliterans syndrome, and cystic fibrosis after lung transplantation. J Heart Lung Transplant 2013;32:70-7.

162. Loverre A, Tataranni T, Castellano G, Divella C, Battaglia M, Ditonno P, et al. IL-17 expression by tubular epithelial cells in renal transplant recipients with acute antibody-mediated rejection. Am J Transplant 2011;11:1248-59.

163. Abadja F, Sarraj B, Ansari MJ. Significance of T helper 17 immunity in transplantation. Curr Opin Organ Transplant 2012;17:8-14.

164. Zhang Q, Reed EF. Non-MHC antigenic targets of the humoral immune response in transplantation. Curr Opin Immunol 2010;22:682-8

165. Foteinos G, Afzal AR, Mandal K, Jahangiri M, Xu Q. Anti-heat shock protein 60 autoantibodies induce atherosclerosis in 
apolipoprotein E-deficient mice via endothelial damage. Circulation 2005;112:1206-13.

166. Moser B, Szabolcs MJ, Ankersmit HJ, Lu Y, Qu W, Weinberg A, et al. Blockade of RAGE suppresses alloimmune reactions in vitro and delays allograft rejection in murine heart transplantation. Am J Transplant 2007;7:293-302.

167. Pockley AG, Muthana M. Heat shock proteins and allograft rejection. Contrib Nephrol 2005;148:122-34.

168. Wang S, Schmaderer C, Kiss E, Schmidt C, Bonrouhi M, Porubsky S, et al. Recipient Toll-like receptors contribute to chronic graft dysfunction by both MyD88- and TRIF-dependent signaling. Dis Model Mech 2010;3:92-103.

169. Wei W, Chen M, Zhu Y, Wang J, Zhu P, Li Y, et al. Down-regulation of vascular HMGB1 and RAGE expression by n-3 polyunsaturated fatty acids is accompanied by amelioration of chronic vasculopathy of small bowel allografts. J Nutr Biochem 2012;23:1333-40.

170. Kis-Toth K, Szanto A, Thai TH, Tsokos GC. Cytosolic DNA-activated human dendritic cells are potent activators of the adaptive immune response. J Immunol 2011;187:1222-34.

171. Seto T, Kamijo S, Wada Y, Yamaura K, Takahashi K, Komatsu K, et al. Upregulation of the apoptosis-related inflammasome in cardiac allograft rejection. J Heart Lung Transplant 2010;29:352-9.

172. Duan L, Wang CY, Chen J, Gong Q, Zhu P, Zheng F, et al. High-mobility group box 1 promotes early acute allograft rejection by enhancing IL-6-dependent Th17 alloreactive response. Lab Invest 2011;91:43-53.

173. Rao DA, Pober JS. Endothelial injury, alarmins, and allograft rejection. Crit Rev Immunol 2008;28:229-48.

174. Yin Y, Pastrana JL, Li X, Huang X, Mallilankaraman K, Choi ET, et al. Inflammasomes: Sensors of metabolic stresses for vascular inflammation. Front Biosci 2013;18:638-49.

175. Grebe A, Latz E. Cholesterol crystals and inflammation. Curr Rheumatol Rep 2013;15:313.

176. Keller MR, Burlingham WJ. Loss of tolerance to self after transplant. Semin Immunopathol 2011;33:105-10.

177. Chung BH, Kim KW, Kim BM, Piao SG, Lim SW, Choi BS, et al. Dysregulation of Th17 cells during the early post-transplant period in patients under calcineurin inhibitor based immunosuppression. PLoS One 2012;7:e42011.

178. Mitsdoerffer M, Lee Y, Jager A, Kim HJ, Korn T, Kolls JK, et al. Proinflammatory T helper type 17 cells are effective B-cell helpers. Proc Nat Acad Sci USA 2010;107:14292-7.

179. He Z, Shotorbani SS, Jiao Z, Su Z, Tong J, Liu Y, et al. HMGB1 promotes the differentiation of Th17 via up-regulating TLR2 and IL-23 of CD14 $4^{+}$monocytes from patients with rheumatoid arthritis. Scand J Immunol 2012;76:483-9.

180. Wilson JM, Kurtz CC, Black SG, Ross WG, Alam MS, Linden J, et al. The A2B adenosine receptor promotes Th17 differentiation via stimulation of dendritic cell IL-6. J Immunol 2011;186:6746-52.

181. Ciubotariu R, Liu Z, Colovai AI, Ho E, Itescu S, Ravalli S, et al. Persistent allopeptide reactivity and epitope spreading in chronic rejection of organ allografts. J Clin Invest 1998;101:398-405.

182. Nath DS, Tiriveedhi V, Basha HI, Phelan D, Moazami N, Ewald GA, et al. A role for antibodies to human leukocyte antigens, collagen-V, and $\mathrm{K}$-alpha1-Tubulin in antibody-mediated rejection and cardiac allograft vasculopathy. Transplantation 2011;91:1036-43.
183. Harrison DG, Guzik TJ, Lob HE, Madhur MS, Marvar PJ, Thabet SR, et al. Inflammation, immunity, and hypertension. Hypertension 2011;57:132-40.

184. Birukov KG. Cyclic stretch, reactive oxygen species, and vascular remodeling. Antioxid Redox Signal 2009;11:1651-67.

185. Ando J, Yamamoto K. Effects of shear stress and stretch on endothelial function. Antioxid Redox Signal 2011;15:1389-403.

186. Schiffrin EL. The Immune System: Role in Hypertension. Can J Cardiol 2013;29:543-8.

187. Ding N, Wang F, Han Y, Xiao H, Xu L, She S. Mitogen-activated protein kinase kinase 6 mediates mechanical stretch-induced high-mobility group box 1 protein expression in pulmonary alveolar epithelial cells. J Trauma Acute Care Surg 2012;72:162-8.

188. Inoue N, Kawashima S, Hirata KI, Rikitake Y, Takeshita S, Yamochi W, et al. Stretch force on vascular smooth muscle cells enhances oxidation of LDL via superoxide production. Am J Physiol 1998;274:H1928-32.

189. Luo SS, Sugimoto K, Fujii S, Takemasa T, Fu SB, Yamashita K. Role of heat shock protein 70 in induction of stress fiber formation in rat arterial endothelial cells in response to stretch stress. Acta Histochem Cytochem 2007;40:9-17.

190. Nakamura T, Sato E, Fujiwara N, Kawagoe Y, Yamada S, Ueda Y, et al. Changes in urinary albumin excretion, inflammatory and oxidative stress markers in ADPKD patients with hypertension Am J Med Sci 2012;343:46-51.

191. Bauer EM, Shapiro R, Zheng H, Ahmad F, Ishizawar D, Comhair SA, et al. High mobility group box 1 contributes to the pathogenesis of experimental pulmonary hypertension via activation of Toll-like receptor 4. Mol Med 2013;18:1509-18.

192. Dunzendorfer S, Lee HK, Tobias PS. Flow-dependent regulation of endothelial Toll-like receptor 2 expression through inhibition of SP1 activity. Circ Res 2004;95:684-91.

193. Li BH, Zhang LL, Pi Y, Yin YW, Yang QW, Fang CQ, et al. Role of toll like receptor 4 in low shear stress-induced intimal hyperplasia (English written abstract). Zhonghua Yi Xue Za Zhi 2012;92:773-7.

194. Li Y, Liu S, Zhang Z, Xu Q, Xie F, Wang J, et al. RAGE mediates accelerated diabetic vein graft atherosclerosis induced by combined mechanical stress and AGEs via synergistic ERK activation. PLoS One 2012;7:e35016.

195. DeVerse JS, Bailey KA, Jackson KN, Passerini AG. Shear stress modulates RAGE-mediated inflammation in a model of diabetes-induced metabolic stress. Am J Physiol Heart Circ Physiol 2012;302:H2498-508.

196. Udani S, Lazich I, Bakris GL. Epidemiology of hypertensive kidney disease. Nat Rev Nephrol 2011;7:11-21.

197. Azibani F, Fazal L, Chatziantoniou C, Samuel JL, Delcayre C. Hypertension-induced fibrosis: A balance story. Ann Cardiol Angeiol (Paris) 2012;61:150-5.

198. Skogstrand T, Leh S, Paliege A, Reed RK, Vikse BE, Bachmann S, et al. Arterial damage precedes the development of interstitial damage in the nonclipped kidney of two-kidney, one-clip hypertensive rats. J Hypertens 2013;31:152-9.

199. Palm F, Nordquist L. Renal oxidative stress, oxygenation, and hypertension. Am J Physiol Regul Integr Comp Physiol 2011;301:R1229-41. 
200. Badiou S, Cristol JP, Mourad G. Dyslipidemia following kidney transplantation: Diagnosis and treatment. Curr Diab Rep 2009;9:305-11.

201. Land WG. Aging and immunosuppression in kidney transplantation. Exp Clin Transplant 2004;2:229-37.

202. Rezzani R. Exploring cyclosporine A-side effects and the protective role-played by antioxidants: The morphological and immunohistochemical studies. Histol Histopathol 2006;21:301-16.

203. Keane T, Egan D, Ryan MP. Signalling pathways involved in cyclosporine A-induced TGF- $\beta 1$ secretion from a renal tubular epithelial cell line. J Am Soc Nephrol 1998;9:A3045.

204. McMorrow T, Gaffney MM, Slattery C, Campbell E, Ryan MP. Cyclosporine A induced epithelial-mesenchymal transition in human renal proximal tubular epithelial cells. Nephrol Dial Transplant 2005;20:2215-25.

205. Lim SW, Li C, Ahn KO, Kim J, Moon IS, Ahn C, et al. Cyclosporine-induced renal injury induces toll-like receptor and maturation of dendritic cells. Transplantation 2005;80:691-9.

206. Ghee JY, Han DH, Song HK, Kim WY, Kim SH, Yoon HE, et al. The role of macrophage in the pathogenesis of chronic cyclosporine-induced nephropathy. Nephrol Dial Transplant 2008;23:4061-9.

207. Yoon HE, Yang CW. Established and newly proposed mechanisms of chronic cyclosporine nephropathy. Korean J Intern Med 2009;24:81-92.

208. Dupont PJ, Manuel O, Pascual M. Infection and chronic allograft dysfunction. Kidney Int Suppl 2010;119:S47-53.

209. Ribeiro A, Wörnle M, Motamedi N, Anders HJ, Gröne EF, Nitschko $\mathrm{H}$, et al. Activation of innate immune defense mechanisms contributes to polyomavirus BK-associated nephropathy. Kidney Int 2012;81:100-11.

210. Hirsch HH, Randhawa P; the AST Infectious Diseases Community of Practice. BK polyomavirus in solid organ transplantation. Am J Transplant 2013;13:179-88.

211. Erridge C. The roles of pathogen-associated molecular patterns in atherosclerosis. Trends Cardiovasc Med 2008;18:52-6.

212. Rosenfeld ME, Campbell LA. Pathogens and atherosclerosis: Update on the potential contribution of multiple infectious organisms to the pathogenesis of atherosclerosis. Thromb Haemost 2011;106:858-67.

213. Valantine HA. The role of viruses in cardiac allograft vasculopathy. Am J Transplant 2004;4:169- 77.

214. Streblow DN, Orloff SL, Nelson JA. Acceleration of allograft failure by cytomegalovirus. Curr Opin Immunol 2007;19:577-82.

215. Dzabic M, Rahbar A, Yaiw KC, Naghibi M, Religa P, Fellström B, et al. Intragraft cytomegalovirus protein expression is associated with reduced renal allograft survival. Clin Infect Dis 2011;53:969-76.

216. Schwab I, Nimmerjahn F. Intravenous immunoglobulin therapy: How does IgG modulate the immune system? Nat Rev Immunol 2013;13:176-89.

217. Cousens LP, Najafian N, Mingozzi F, Elyaman W, Mazer B, Moise L, et al. In vitro and in vivo studies of IgG-derived Treg epitopes (Tregitopes): A promising new tool for tolerance induction and treatment of autoimmunity. J Clin Immunol 2013;33:S43-9.

218. Maddur MS, Sharma M, Hegde P, Lacroix-Desmazes S, Kaveri SV, Bayry J. Inhibitory effect of IVIG on IL-17 production by Th17 cells is independent of anti-IL-17 antibodies in the immunoglobulin preparations. J Clin Immunol 2013;33:62-6. 